\title{
Bacterial technology-enabled cementitious composites: A review
}

\author{
Linwei Li ${ }^{1, \uparrow}$, Qiaofeng Zheng ${ }^{1, \star}$, Zhen $\mathrm{Li}^{1}$, Ashraf Ashour ${ }^{2}$, Baoguo Han ${ }^{1, *}$ \\ ${ }^{1}$ School of Civil Engineering, Dalian University of Technology, Dalian 116024, China \\ ${ }^{2}$ Faculty of Engineering \& Informatics, University of Bradford, Bradford, BD7 1DP, UK \\ $\dagger, \$$ Linwen Li and Qiaofeng Zheng contributed equally, and they are alphabetically ordered. \\ * Corresponding author: hithanbaoguo@163.com, hanbaoguo@dlut.edu.cn
}

\begin{abstract}
Cementitious composites are generally brittle and develop considerable tension cracks, resulting in corrosion of steel reinforcement and compromising structural durability. With careful selection and treatment, some kinds of bacteria are able to precipitate calcium carbonate and 'heal' cracks in cementitious composites through their metabolism, namely bacterial activity. It is envisioned that the bacterial technology-enabled cementitious composites could have great potential for engineering applications such as surface treatment, crack repair and self-healing construction material. This paper presents the state-of-the-art development of bacterial technology-enabled cementitious composites from the following aspects: mechanisms of bacterial induced calcium carbonate precipitation; methods of applying bacteria into cementitious composites; mechanical properties, durability and their influencing factors; various applications; cost effective analysis and prospect. The paper concludes with an outline of some future opportunities and challenges in the application of bacterial technology-enabled cementitious composites in construction.
\end{abstract}

Key Words: Bacterial induced calcium carbonate precipitation; principle of technology-enabled cementitious composites; mechanical properties and durability

\section{1. Introduction}

2 Traditional cementitious composites suffer from several drawbacks including low tensile strength leading

3 to the growth of tension cracks, which allows in harmful liquids and gases, resulting in corrosion of steel

4 reinforcement and low structural durability eventually [1]. Bacterial technology has emerged as a

5 promising method to address these issues. It is found that certain kinds of bacteria can participate calcium

6 carbonate when incorporated into cementitious composites, which is actually a common phenomenon in nature $[2,3]$. Upon this finding, bacterial technology-enabled cementitious composites have been regarded as environmentally friendly and cost-effective materials with a great potential for a wide range of engineering applications [4].

10 Due to their unique bacterial precipitation activity, bacterial technology-enabled cementitious composites have shown the capability of enhancing structural durability and mechanical properties, such as compressive strength, permeability, porosity, etc. [5-8]. Incorporating bacteria into cementitious 
composites during mixing has been used for crack control purpose which is mainly achieved by bacterial precipitation [9]. Compared with other traditional healing agents such as acrylic resin and silicone-based polymers, bacteria are more favored because the precipitated substances such as calcium carbonate have excellent mechanical and thermal compatibility with cementitious matrix $[10,11]$. The bacterial technology endows cementitious materials with self-healing ability and significantly reduces the repair cost and labor intensity, especially for the remediation of large-scale concrete infrastructures such as tunnels and highways in service [12]. It is also believed, with this bacterial technology, the lifespan of cementitious materials and structures can be largely extended, contributing to addressing the rising concern in cement industry which accounts for $8 \%-10 \%$ of global $\mathrm{CO}_{2}$ emissions [13].

The past decade has witnessed a significant growth in studies on bacterial technology-enabled cementitious composites; this paper offers to summarize the state-of-the-art developments in this field. The principle of bacterial technology-enabled cementitious composites is introduced, providing a comprehensive basic theory of how this material realizes crack healing and its specific procedure. How bacterial precipitation changes mechanical properties and durability of cementitious composites is reviewed, with emphasis on influencing factors such as bacteria type, bacteria concentration and nutrients. Possible applications including self-healing material, crack repairment solution and surface treatment solution are also presented in this paper. Finally, cost analysis including benefits to cost ratio and potential methods to reduce cost are also discussed.

\section{Principle of bacterial technology-enabled self-healing cementitious composites}

\subsection{Mechanisms of bacterial induced calcium carbonate precipitation}

Crack-healing ability of bacterial technology-enabled cementitious composites is realized by bacterial induced calcium carbonate precipitation from two main routes. On the one hand, certain bacteria can make use of carbon source to produce carbon dioxide or carbonate ion which will react with calcium ions to form bacterial calcium carbonate precipitation [2]. The bacterial activity will create an alkaline environment, in favor of the process of bacterial precipitation. Generally, to survive the harsh and already alkaline environment inside cementitious composites, alkaliphilic and spore-forming bacteria should be the first choice [2]. On the other hand, bacteria provide nucleation sites for bacterial calcium carbonate precipitation. Because the cell wall of the bacteria is negatively charged, the bacteria can draw cations from the environment, including positively charged calcium ions which deposit on their cell wall surfaces. The calcium ions then react with the carbonate ions leading to bacterial precipitation at the cell surface 
1 [12] (Eqns. 1, 2). Then, this precipitation serves as the nucleation sites as well to facilitate healing process.

2 With the assistance of localized bacterial precipitation, the cracked faces of cementitious composites can

3 be filled $[2,12]$ (as shown in Fig. 1-2).

$4 \quad \mathrm{Ca}^{2+}+\mathrm{Cell} \rightarrow$ Cell-Ca ${ }^{2+}$

Equation (1)

Cell- $\mathrm{Ca}^{2+}+\mathrm{CO}_{3}^{2-} \rightarrow$ Cell- $\mathrm{CaCO}_{3} \quad$ Equation (2)

6 Many bacteria can precipitate calcium carbonate based on different metabolic pathways, namely bacterial activities (Table 1) [14]. Specific processes of part of bacterial activities in Table 1, including photosynthesis, dissimilatory sulfate reduction, denitrification $\left(\mathrm{NO}_{\mathrm{x}}\right.$ reduction) and urea hydrolysis, are listed in Table $2[15,16]$. Among them, photosynthesis always appears in aquatic environment. Dissimilatory sulfate reduction is carried out by sulfate reducing bacteria, which usually occurs under anoxic conditions. Denitrification requires the degradation of organic acids and has great potential for calcium carbonate precipitation. This type of bacteria has an ideal process to produce carbonate precipitation due to the simple production of nitrogen and carbon dioxide. However, it has been rarely studied so far. Ersan et al. [17] applied Diaphorobacter nitroreducens, a kind of bacteria with bacterial activity of denitrification, to investigate what they believed as a more promising bacteria protective material and the result showed bacteria associated with protection material of expanded clay contribute to an enhancement in compressive strength. Another approach to calcium carbonate precipitation, which has aroused great interest of researches, is to use bacteria with capability of urea hydrolysis [16]. This type of bacteria is popular because the hydrolysis of urea can occur in a short period of time and generate carbonate ions without unneeded protons $[11,16]$. Fig. 1 illustrates the schematic diagram of the events occurring during bacterial precipitation through urea hydrolysis [18]. Firstly, bacteria attract calcium ions, and dissolves urea into dissolved inorganic carbon and ammonium; secondly, bacterial precipitation occurs on the bacterial cell wall; then the whole cell becomes encapsulated; lastly, the imprints of bacterial cells is on bacterial precipitation [18]. In the process of precipitation, bacterial cells play an important role. Pei et al. [19] verified that using of bacterial cell walls in cementitious composites, which can neglect the viability issue of using live bacteria, have the potential to be an admixture of cementitious composites benefiting enhancement of not only mechanical performance, but also other carbonation-related properties. Williams et al. [20] also reported that specimen with bacteria cell walls obtained $62 \%$ and $33 \%$ of more calcium carbonate than conventional specimens with or without nutrients, respectively. Overall, these studies suggest that with 
careful selection, bacteria are able to, whether viable or not, serve as nucleation sites for calcium carbonate precipitation in cementitious composites $[19,20]$.

\subsection{Methods of applying bacteria into cementitious composites}

Bacterial precipitation can be achieved in various methods of applying bacteria into cementitious composites, all of which are based on bacterial activity. However, with different applying methods, composite performances such as durability and life span would be different. So far, three methods, namely direct application, immobilization and encapsulation, have been widely investigated, and, for the last two methods, protective materials such as silica gel and clay are demanded to prolong bacteria life. Table 3 displays methods of applying bacteria into cementitious composites and characteristic of various protective materials.

\subsubsection{Direct application}

Direct application can be divided into two types. One is to apply the solution containing bacteria and nutrients into cementitious composites, then a coating layer of carbonate precipitation will be produced on the surface of the materials, in which way the durability of the specimen or the structure is enhanced (as shown in Fig. 3(a)(c)). There are three implementation methods: immersing cementitious composites into solution, spraying or brushing the solution on cementitious composites [21]. Choi et al. [22] applied a solution containing Bacillus Pasteurii and urea- $\mathrm{CaCl}_{2}$ in pre-cracked specimen. After treating the cementitious composites with the solution 21 times to accelerate bacterial precipitation, the permeability of all the specimens with cracks width from 0.15 to $1.64 \mathrm{~mm}$ was observed to decrease [22]. Sangadjia et al. [23] used alkaliphilic bacteria and nutrient solution for porous network cementitious composites, and found the precipitation could seal the cracks in the matrix, and multiple times of treatment using bacteria and nutrients solution appeared to be a more efficient way than single time treatment to obtain sufficient bacterial precipitation.

Another technique of direct application (also called direct incorporation) is to incorporate bacteria into cementitious material during the mixing procedure without protective material [4]. Ghosh et al. [24] observed that bacterial participation could fill the pores in specimen, thus reducing the total pore volumes in matrix, and consequently, enhancing compressive strength. Apparently, this method makes it easier for fabrication, with a potential consequence of cost reduction. However, it dramatically influences the bacterial activity because hydration of cement is a continuous process which reduces the pore size of cement paste and crushes the spores $[5,11]$. The viability of bacterial spores will be reduced drastically 
1 with increasing age of cementitious composites [5].

2 Recently, a new example of direct incorporation was studied. Jadhav et al. [25] applied bacteria directly

3 into cementitious composites with geopolymer and found that this material did not cause any damage to

4 the bacteria cells applied in specimens directly and crack with average width of $89 \pm 3 \mu \mathrm{m}$ was sealed

5 completely. The great healing capacity was mainly attributed to the presence of large interconnected

6 pores in the metakaolin-based geopolymer used in this study, which provided sufficient space for the

7 growth of bacteria and made bacteria easy to be reactivated [25].

\section{2.2.2. Immobilization}

9 A major obstacle for the incorporation of bacteria in cementitious composites is its harsh alkaline environment, relatively small pore size and dry condition. Consequently, unprotected bacterial could not 11 remain viable in long term [17]. Bacteria without any protective methods are not able to fill the cracks completely [26]. To ensure the long-term effectiveness of bacteria, immobilization, a method to incorporate bacteria with protective material into cementitious composites, has been proposed.

Self-healing efficiency of specimens with bacteria immobilized by protective material was higher than those of direct incorporation (as shown in Table 3). It is also observed that different protective materials have varying efficiencies. Khaliq et al. [27] reported bacteria immobilized in graphite nano-platelets were more effective to heal specimens pre-cracked at 3 and 7 days, while bacteria immobilized in light weight aggregates gave better results at 14 and 28 days. Apart from improvement of viability of bacteria, protective materials can act as fillers and water/nutrients reservoir. According to Charpe et al. [28], addition of nutrients might lead to negative effect on cementitious composites matrix. However, the negative impact of nutrient could be avoided if nutrients are immobilized in carriers [29]. Xu et al. [30] indicated when nutrients and bacteria were immobilized in ceramsite at the same time, nutrients could be more accessible to the bacteria. Bundur et al. [31] verified that specimen with bacteria and nutrients immobilized in pre-wetted lightweight fine expanded shale aggregates had substantial loss in strength.

Recently, multiple protective materials of immobilization have been developed. Calcium sulphoaluminate cement as protective material was studied by Xu et al. [31] and iron oxide nanoparticles was studied by Seifan et al. [32, 33]. Besides, some researchers have investigated using recycled construction materials as protective materials. Crushed brick aggregate used by Manzur et al. [34] is one of them. 


\subsubsection{Encapsulation}

2 It should be noted that risks exist that the bacterial cells could be damaged during the stage of mixing,

3 setting and hardening of cementitious composites [4]. To ensure bacteria viability for realizing a more

4 effective self-healing ability during these processes, encapsulation of bacteria in protective carriers is

5 preferable (as shown in Table 3). Suitable carriers can act as a shell to protect bacteria and have no

6 hindering effect on bacterial precipitation and scarcely any negative effect on the cementitious

7 composites [4]. Besides, to reduce the negative impact of the nutrients on the engineering performance, encapsulation of the nutrients has also been proposed [35]. Bacteria and nutrients are first encapsulated into protective materials and, then, incorporated into specimens. Encapsulation splits once cracks or micro-cracks occur, then healing agent is released to make a difference (as shown in Fig. 4) [36].

Wang et al. [4] investigated self-healing efficiency of cementitious composites with bacterial spores encapsulated into hydrogels. Hydrogel was used as the bacterial carriers and water reservoirs for continuous crack healing. The result showed that bacterial precipitation in or on hydrogel occurred and cracks of a width $0.5 \mathrm{~mm}$ in the specimens can be completely healed [4]. Wang et al. [37] explored the use of silica gel or polyurethane as the carrier encapsulated into glass tube with the bacteria together. They concluded that bacteria encapsulated by silica gel exhibited a higher activity than bacteria encapsulated by polyurethane and hence, more $\mathrm{CaCO}_{3}$ precipitated in silica gel of $25 \%$ (by mass of silica gel sample) than in polyurethane (PU) of $11 \%$ (by mass polyurethane foam sample). However, precracked specimens healed by bacteria encapsulated by polyurethane exhibited a higher strength regain and lower water permeability [37]. In general, the application of encapsulation protective material enhances the viability of bacteria cells indeed, but further studies are still required to ensure both the viability of bacteria cells and mechanical performance of the healed composites.

\section{Properties of bacterial technology-enabled cementitious composites}

\subsection{Micro-structural analysis}

It is necessary to look into the microstructure of bacterial technology-enabled cementitious composites by methods like SEM, EDS, XRD and TGA, so as to ascertain the feasibility of adding bacteria into cementitious composites and provide well-grounded support for their macroscopic properties. As shown in Fig. 5(a), there is a decrease in weight of the composites between $500^{\circ} \mathrm{C}$ and $800{ }^{\circ} \mathrm{C}$ detected by TGA, which is resulted from the decomposition of $\mathrm{CaCO}_{3}$, and there is an apparent difference in weight loss in specimens with active or autoclaved bacteria, providing evidence that particularly in the case of active 
1 bacteria, more $\mathrm{CaCO}_{3}$ crystals are formed in the process of self-healing [26]. It is also shown in Table 4

2 that bacterial type, bacterial concentration and nutrients have significant influence on the presence of

3 bacterial precipitation.

4 First, bacterial type affects precipitation morphology to a large extent. Bhaskar et al.[38] stated that

5 precipitation morphology of Sporosarcina ureae tended to be relatively denser rhombohedral-shaped crystals, while that of Sporosarcina pasteuri tended to be relatively scatter (as shown in Fig.6). Kim et al.

7 [10] compared precipitation morphology of S. pasteurii and B. sphaericus, and indicated that the former was denser in smaller spherical or semi-spherical particle shapes while the latter was in pockmark shapes.

9 Some other researches are listed in Table 4.

In addition, nutrients, a single or compound substance for accelerating bacterial precipitation, affects

11 morphology significantly. Zhang et al. indicated that precipitation of monopoly of $\mathrm{CaCl}_{2}, \mathrm{Ca}\left(\mathrm{NO}_{3}\right)_{2}$,

$\mathrm{Ca}\left(\mathrm{CH}_{3} \mathrm{COO}\right)_{2}$ was hexahedral crystals with rough surface, acicular crystals, small amount of spherical and lettuce-like crystals respectively [39]. Amiri et al. [40] and Tittelboom et al. [26] also indicated that different calcium source will result in different morphology of precipitation. As shown in Fig. 5, in case of specimen with $\mathrm{CaCl}_{2}$ and $\mathrm{Ca}\left(\mathrm{CH}_{3} \mathrm{COO}\right)_{2}$, the first and second peaks of TGA curves appear at $610{ }^{\circ} \mathrm{C}$ and $735{ }^{\circ} \mathrm{C}$ and at $628{ }^{\circ} \mathrm{C}$ and $768^{\circ} \mathrm{C}$, respectively. Due to the better stability of calcite than vaterite, specimen with $\mathrm{Ca}\left(\mathrm{CH}_{3} \mathrm{COO}\right)_{2}$ obsessed more calcite than that with $\mathrm{CaCl}_{2}$ (above $600{ }^{\circ} \mathrm{C}$ in Fig.5) by TGA analysis. In addition, Amiri et al. [40] also researched the impact of nutrients besides calcium source. In his researches, corn steep liquor with tris base and urea (UCSL) and urea-yeast extract (UYE) were used, and there was no difference observed in morphology of precipitation. Zeta potential of bacteria was tested, a factor affecting the density and the amount of the precipitation since it would relate to the nucleation sites [40]. And there is no difference of Zeta potential between the two bacteria. Amiri et al. [40] indicated surface charge of the cells did not affect precipitation morphology but had the potential to lead to various precipitation density.

Furthermore, bacterial concentration will not reflect on precipitation morphology but amount of precipitation and its forming rate[41]. In research of Andalib et al.[42], the amount of calcium obtained by specimen with bacterial concentration of $20 \times 10^{5}, 30 \times 10^{5}$, and $40 \times 10^{5} \mathrm{cfu} / \mathrm{ml}$ was found to be $32.89 \%$, $38.76 \%$, and $24.92 \%$ by EDS, whereas the calcite intensity was found to be 590, 1092, and 428 using XRD [42]. Mondal et al. indicated that higher cell concentrations lead to higher precipitation amount in 
the crack surface, which results in absence of water and oxygen in inner matrix, and the total precipitation amount may not occur in specimen with higher cell concentrations [41].

\subsection{Mechanical properties}

\subsubsection{Compressive strength}

The improvement of compressive strength is mainly attributed to bacterial induced calcium carbonate precipitation within the pores of the cementitious composites matrix as observed by the scanning electron microscopy (SEM) [24]. Rao et al. [43] found that, with the addition of bacteria, compressive strength of specimen showed a significant increase by nearly $25 \%$ in all grades of cementitious composites as the voids and pores were sealed up by bacterial precipitation. Porter et al. [44] reported that the addition of bacteria in road base containing 7\% cement and sand led to an increase between 33\% and 50\% of unconfined compressive strength compared with the sample without bacteria, because rhombohedral crystals were observed to be able to reinforce the bridges of interface between cement grain and sand. In research conducted by Chahal et al. [45], the cementitious composites specimen with bacteria and without bacteria were analyzed for the growth of calcium carbonate crystals by SEM. The matrix of the specimen without bacteria appeared to be amorphous, showing no sign of crystal growth while, in the specimen with bacteria, individual crystals could be observed [45]. In recent research, Qian et al. [46] revealed the evolution law of microstructure by X-ray computed tomography (X-CT) technique. The atomic binding energy of $\mathrm{C}-\mathrm{O}$ bond in precipitation, $\mathrm{Si}-\mathrm{O}$ bond and $\mathrm{Si}$ in sand analysis showed that precipitation interacted with surface of loose sand particles formed the intermolecular hydrogen bond, which is another explanation for strength improvement [46]. Meanwhile, the results of other researches also suggest that the compressive strength after healing depends on many factors, including the type and the concentration of bacteria and nutrients (as shown in Fig. 7).

Researches on the influence of bacteria type on compressive strength are summarized in Table 5. Ghosh et al. [24] indicated that although bacterial precipitation within the pores of matrix was also observed, no improvement of compressive strength was recorded in specimens with E. coli bacteria. In the research conducted by Jagannathan [47], specimens with Bacillus Sphaericus exhibited a compressive strength improvement of $10.8 \%$, while Bacillus Pasteurii showed a decrease of $9.8 \%$ compared to conventional specimen. Bhaskar et al. [38] investigated the compressive strength of cementitious composites incorporated by Sporosarcina ureae and Sporosarcina pasteurii respectively. The results indicated that, in the long term (270 days), the performance of specimens with Sporosarcina ureae was around $8 \%$ lower 
than that with Sporosarcina pasteurii [38]. From Fig. 6, the precipitated calcite crystals by Sporosarcina pasteurii is denser than that formed by Sporosarcina ureae, implying that the bonding between the crystals may be strong, and the crystals precipitated by Sporosarcina pasteurii is larger than the ones formed by Sposarcina ureae [38]. Bhaskar et al. [38] inferred that the difference in $\mathrm{CaCO} 3$ precipitation between the two bacterial species may be attributed to the different capabilities of providing various types of urease enzymes. Bacteria concentration also has a significant impact on compressive strength. Mondal et al. [41] found that compressive strength was increased by $15 \%, 27 \%$ and $19 \%$ with cell concentrations of $10^{3}$ cells $\cdot \mathrm{ml}^{-1}, 10^{5}$ cells $\cdot \mathrm{ml}^{-1}$ and $10^{7}$ cells $\cdot \mathrm{ml}^{-1}$, respectively. Similar results were obtained by Chahal et al. and Rao et al. [43, 48], who suggested that $10^{5}$ cells $\cdot \mathrm{ml}^{-1}$ was the most effective bacteria concentration for strength improvement, beyond which it failed to keep pace with concentration growth. The main reason for this might be disruption of cementitious composites matrix integrity with the presence of organic matter in the form of biomass due to high concentration of bacteria [43]. In addition, more detailed experiments about different bacteria concentration were conducted. Andalib et al. [42] investigated the compressive strength increase of specimens with bacteria concentration of $20 \times 10^{5}$, $30 \times 10^{5}$, and $40 \times 10^{5} \mathrm{cfu} \cdot \mathrm{ml}^{-1}(\mathrm{cfu}$ : colony-forming units), and found maximum compressive strength increase was $24 \%$ which occurred in specimen with maximum intensity of $\mathrm{CaCO}_{3}$, i.e. specimen with $30 \times 10^{5} \mathrm{cfu} \cdot \mathrm{ml}^{-1}[42] . \mathrm{XRD}$ analysis showed that maximum intensity of $\mathrm{CaCO}_{3}$ were 590 a.u. (arbitrary unit), 1092 a.u. and 428 a.u. with bacteria concentration of $20 \times 10^{5}, 30 \times 10^{5}$, and $40 \times 10^{5} \mathrm{cfu} \cdot \mathrm{ml}^{-1}$ respectively, identifying the relationship between bacterial concentration and compressive strength [42]. Moreover, the amount of calcium in specimens was found to be $32.89 \%, 38.76 \%$, and $24.92 \%$ of total sample mass with bacteria concentration of $20 \times 10^{5}, 30 \times 10^{5}$, and $40 \times 10^{5} \mathrm{cfu} \cdot \mathrm{ml}^{-1}(\mathrm{cfu}$ : colony-forming units) respectively by Energy Dispersive Spectrometer (EDS) [42]. Reduction flowability of water inside the cementitious composites at an early stage may also affect the hydration of cement, which can be an explanation for the reduction of compressive strength at higher bacterial concentration[41]. Bacterial precipitation in the inner matrix is less due to lack of water and oxygen [41]. Table 5 shows the researches about the influence of bacteria concentration on compressive strength.

Nutrients also play an important role in compressive strength. A phenomenon was observed by Joshi et al. and Ersan et al. $[17,49]$ that the addition of nutrients without bacteria in specimens showed distinctive decrease in compressive strength (as shown in Table 5). However, the negative effect of addition of only nutrients into cementitious composites is diminished when it is added along with bacteria together [49]. 
1 Meanwhile, by providing enough calcium sources and substances that bacterial activities needed,

2 bacterial precipitation is enhanced and accelerated [29]. According to Xu et al. [29], lower regain ratio

3 of compressive strength was obtained in bacterial technology-enabled cementitious composites without

4 nutrients. Joshi et al. [49, 50] indicated that addition of nutrients of corn steep liquor and nutrient broth

5 with urea-CaCl 2 in bacterial technology-enabled cementitious composites contributed to an increase of

$625 \%$ and $29 \%$ of compressive strength, respectively. Generally, the natural precipitation process is slow,

7 so the application of nutrients is in demand to accelerate precipitation, and compound nutrients are better

8 than the single one $[11,51]$. Thiyagarajan et al. [52] indicated that specimens with waste water which

9 contained composite nutrients, had a better performance of compressive strength than that with one single

nutrient. Based on bacterial experiments, more rapid and efficient bacterial precipitation occurs in the

11 presence of other nutrients rather than in nutrients comprising of just yeast extract [53]. The main reason

for nutrient's influence on compressive strength lies with its significant impact on crystal size and morphology [39]. Crystal growth can be inhibited or altered by the absorption of organic matter or inorganic components to specify crystallographic planes of the growing crystal [54]. According to experiments conducted by Zhang et al. [39], specimens with $\mathrm{Ca}\left(\mathrm{CH}_{3} \mathrm{COO}\right)_{2}$ presented a more uniform pore distribution over a wide range and bacterial precipitation had an aragonite crystal with acicular mineral morphology. The results showed that the uniaxial compressive strength of specimen with $\mathrm{Ca}\left(\mathrm{CH}_{3} \mathrm{COO}\right)_{2}$ were about twice of those with $\mathrm{CaCl}_{2}$ and $\mathrm{Ca}\left(\mathrm{NO}_{3}\right)_{2}$ [39]. In research conducted by Zhang et al. [39], bacterial technology-enabled cementitious composites oxygen releasing tablet (ORT) as one of nutrients was studied. The results showed that amount of calcium precipitation increased after the oxygen was released from oxygen releasing tablet (ORT) which was made of $\mathrm{CaO}_{2}$ [55]. Nevertheless, there is no research on the crack healing efficiency and mechanical properties with addition of ORT as bacterial nutrients. Researches investigating the influence of nutrients on compressive strength are summarized in Table 5. compressive strength due to their different protection abilities. Encapsulation and immobilization are better than direct application for enhancing strength of cementitious composites. However, the choice between encapsulation and immobilization cannot be generally concluded as it heavily relies on the protective material used. 
1 The split tensile strength of bacterial technology-enabled cementitious composites has also been widely investigated. According to Choi et al. [22], there was a relationship between the split tensile strength and the amount of bacterial precipitation. It is also related to bacteria type, bacteria concentration and nutrients. Bashir et al. [56] showed that the enhancement of split tensile strength of specimens with B. Subtilis and B. Sphaericus was $38.17 \%$ and $31.14 \%$ at 7 days, $14.41 \%$ and $2.76 \%$ at 28 days, respectively. Jagannathan et al. [47] also indicated that split tensile strength in specimen with Bacillus sphaericus was higher than tha twith by Bacillus Pasteurii. As for bacteria concentration, Kadapure et al. [13] indicated that maximum increase in split tensile strength was found to be $20.75 \%$ at a concentration of $10^{5} \mathrm{cells} / \mathrm{ml}$ of Bacillus sphaericus at 7 days among $10^{3}$ cells $/ \mathrm{ml}, 10^{5}$ cells $/ \mathrm{ml}$ and $10^{7}$ cells $/ \mathrm{ml}$. Types of nutrients and their concentration also make a profound effect on split tensile strength. Zhang et al. [39] investigated the influence of different calcium sources $\left(\mathrm{CaCl}_{2}, \mathrm{Ca}\left(\mathrm{CH}_{3} \mathrm{COO}\right)_{2}\right.$ and $\left.\mathrm{Ca}\left(\mathrm{NO}_{3}\right)_{2}\right)$ on split tensile strength, and the results showed that the split tensile strength of specimens treated with $\mathrm{Ca}\left(\mathrm{CH}_{3} \mathrm{COO}\right)_{2}$ were about twice those specimens treated with the other two calcium sources. Irwan et al. [51] indicated that the increases of tensile strength obtained in specimens incorporating Enterococcus faecalis with $0.001 \mathrm{~mol} \cdot \mathrm{L}^{-}$ 1, $0.005 \mathrm{~mol} \cdot \mathrm{L}^{-1}$ and $0.01 \mathrm{~mol} \cdot \mathrm{L}^{-1}$ calcium lactate were $0.7 \%, 18.5 \%$ and $1.5 \%$, respectively, and specimens with $0.005 \mathrm{~mol} \cdot \mathrm{L}^{-1}$ calcium lactate showed the best performance.

\subsubsection{Flexural strength}

The flexural strength improvement of cementitious composites is also related to bacteria type, bacteria concentration and nutrients. Bashir et al. [56] found that the enhancement of flexural strength of specimen with B. Subtilis was $17.34 \%$ at 7 days and $11.18 \%$ at 28 days. Jagannathan et al. [47] reported that the flexural strength of specimens with Bacillus Sphaericus was higher than that with Bacillus Pasteurii. Andalib et al. [42] pointed out that bacteria concentration resulting in maximum flexural strength enhancement of $24 \%$ was $30 \times 10 \mathrm{cfu} \cdot \mathrm{ml}^{-1}$ as confirmed by XRD and EDS analysis. Irwan et al. [51] reported that addition of $0.001 \mathrm{~mol} \cdot \mathrm{L}^{-1}, 0.005 \mathrm{~mol} \cdot \mathrm{L}^{-1}$ and $0.01 \mathrm{~mol} \cdot \mathrm{L}^{-1}$ of nutrients could increase the flexural strength by $39.1 \%, 41.0 \%$ and $39.5 \%$ compared with conventional cementitious composites, and by $0.7 \%, 2.1 \%$ and $1 \%$ respectively compared with specimen with bacteria but without nutrients, the highest increase was observed in specimen with $0.005 \mathrm{~mol} \cdot \mathrm{L}^{-1}$ calcium lactate due to crystal morphology of calcium carbonate precipitation and its intensity as explained in 3.1.1.

\subsection{Durability}

During the process of cell growth, bacterial induced calcium carbonate precipitation occurs on surface 
1 of the cell and in the cementitious composites matrix, which results in a denser microstructure and enhanced durability [36]. Improvements have been observed in all key parameters concerning the durability of bacterial technology-enabled cementitious composites, including water absorption, porosity, water permeability and chloride-ion penetration resistance [45]. A summary of these investigations is presented in Table 6.

\subsubsection{Porosity}

The reduction of porosity in bacterial technology-enabled cementitious composite improves integrity of matrix, improves its bonding homogeneously and reduces the probability of cracks [43]. Achal et al. [57] indicated that more than $50 \%$ reduction in the porosity was found in specimens with bacteria of Bacillus sp. CT-5. Rao et al. [43] reported that the porosity of specimens with addition of bacteria was reduced by nearly $70 \%$ according to ultrasonic pulse velocity test as bacterial precipitation in the pores reduced the average pore radius of matrix. As shown in the Fig. 8, the addition of bacteria would shift large pores in cementitious composites into smaller pores with pore size of 0.6-1.6 $\mu \mathrm{m}$, which is exactly the typical size of bacterial spores [32]. Additionally, bacterial precipitation also covers the pores in the surface of specimens, so porosity decreases accordingly [57].

\subsubsection{Water absorption}

Absorption characteristics reflect the volume of pores and their connectivity in cement matrix [43]. As mentioned above, pore size and connection between pores in cementitious composites would be reduced due to the filing by bacteria and precipitation, undermining capillary suction effect and, eventually, resulting in reduction in water absorption. Muynck et al. [54] also indicated the reduction in water absorption resulted from the combined effects of the presence of bacteria in pores and bacterial precipitation. As exhibited in Table 6, the addition of bacteria in cementitious composites can lead to a significant reduction in water absorption. Muynck et al. [58] and Mondal et al. [41] pointed out that this reduction would be also influenced by the type of bacteria, bacteria concentration and different nutrients (as shown in Table 6). In addition, Bhaskar et al. [38] assessed the long-term performance of water absorption and found the highest percentage reduction by $90.43 \%$ was achieved in the specimens with Sporosarcina pasteurii immobilized in zeolite at 8 months.

\subsubsection{Water permeability}

Reduction of the water permeability derives from the reduction of the porosity [43]. Rao et al. [43] reported that water permeability of bacterial technology-enabled cementitious composites reduced by 
nearly $70-90 \%$. Similar to water absorption, bacteria type, bacteria concentration and the nutrients would also alter the improvement effect on water permeability. Irwan et al. [59] reported that the optimal concentration of calcium lactate producing the lowest water penetration was $0.01 \mathrm{~mol} \cdot \mathrm{L}^{-1}$ for both Enterococcus Faecalis and Bacillus sp., which were $8.7 \mathrm{~cm}$ and $8 \mathrm{~cm}$ respectively. Joshi et al. [50] found that, specimens with nutrients of corn steep liquor had the water penetration depth of $28.2 \mathrm{~mm}$, while that of nutrient broth was $31.2 \mathrm{~mm}$.

\subsubsection{Chloride permeability}

Reduction of chloride permeability is also resulted from the improvement of packing density of material particles [43]. Besides, the improvement of aggregate-cement interface by the bacterial precipitation also contributes to decrease the chloride permeability [57]. Rao et al. [43] indicated that bacterial technologyenabled cementitious composites showed an $85 \%$ - 90\% significant improvement of resistance against chloride movement, when compared with that of normal cementitious composites. The same finding was obtained by Achal et al. and Joshi et al. [49, 57]. Bhaskar et al. [38] assessed the long-term performance of chloride permeability and reported that normal cementitious composites specimens with bacteria showed an average decrease in permeability of around $30 \%$ at 120 days, $44 \%$ at 180 days and $54 \%$ at 240 days. Ling et al. [60] assessed the contribution of bacteria added in specimens for protecting reinforcements. Chloride content in different depths showed that addition of bacteria impeded the transmission of chloride in the cracks, blocked corrosion products from overflowing from the cracks and lowered weight-loss ratio of reinforcements, thus slowing down the process of reinforcement corrosion [60]. Chahal et al. $[48,61]$ indicated that the maximum reduction in chloride permeability was observed with optimum bacterial concentration of $10^{5}$ cells $\cdot \mathrm{ml}^{-1}$ in both specimens containing silica fume and fly ash, respectively.

\subsubsection{Freezelthaw and corrosion resistance}

Other research investigations on durability of bacterial technology-enabled cementitious composites are briefly summarized below. It was shown that bacterial technology-enabled cementitious composites having water/cement ratio of 0.7 resulted in a significantly higher splitting tensile strength after 21 freeze/thaw cycles compared with specimens with lower water/cement ratio, owing to the amount of freezable water within the pore system [58]. Ling et al. [60] studied the corrosion degree of steel bar and its weight-loss ratio after electromigration accelerating transmission of chloride in bacterial technology-enabled cementitious composites. The cracks healed by the bacteria and nutrients can better 
1 slow down the transmission of chloride and corrosion of steel bars, indicating that the healed cracks could

2 effectively prevent the chloride ions from invading into the inner matrix [60]. . Tayebani et al. [62]

3 showed that electrical resistance of bacteria technology-enabled cementitious composites increased with

4 addition of S. pasteurii and resistance of steel bars to corrosion also enhanced.

5 In addition, the application method of bacteria also influences durability of cementitious composites to some extent (as shown in Table 3). Encapsulation is the best choice because it is adjustable to severe environment, followed by immobilization technique. Direct method only contributes a little to durability, but treatment of several times would be helpful.

\subsection{Repairable crack width}

The maximum repaired crack width is a valuable assessment factor for self-healing material. Bacterial type has little effect on the maximum repairable crack width which is mainly decided by the application method of bacteria into cementitious composites. For direct application, Qian et al. [63] indicated that cracks of $0.4 \mathrm{~mm}$ width were almost repaired in specimens with Bacillus mucilaginous L3. For immobilization method, Wiktor et al. [64] indicated that cracks of $0.46 \mathrm{~mm}$ width were repaired in specimens with Bacillus alkalinitrilicus immobilized by light weight aggregate. Xu et al. [32] indicated that cracks of $0.42 \mathrm{~mm}$ width healed in specimens with Sporosarcina pasteurii immobilized by calcium sulphoaluminate cement. Khaliq et al. [27] found that cracks with maximum width of $0.52 \mathrm{~mm}$ healed in specimens with Bacillus subtilis immobilized by light weight aggregate. In terms of encapsulation, Wang et al. [4] showed that the maximum healed crack width was about $0.5 \mathrm{~mm}$ in specimens with Bacillus sphaericus encapsulated by hydrogel. According to Vijay et al.[36], maximum crack width of $0.97 \mathrm{~mm}$ was healed using encapsulation method. Overall, the encapsulation method has shown the highest healing efficiency as its good protection ability allows bacteria to produce more calcium carbonate precipitation than direct application and immobilization.

Durability of self-healing ability reflects on practical value of bacterial technology-enabled cementitious composites, which is also a concern of researchers. At early stages after implementation of bacteria, healing property is at the highest efficiency. In research by Mondal et al. [41], it was found that as time goes on, more precipitation was observed (as shown in Fig. 9), and when bacterial concentration was $10^{3}$ cells $/ \mathrm{ml}$ and $10^{5}$ cells $/ \mathrm{ml}$ respectively, cracks are healed by $30 \%, 70 \%$ after 3 days, by $50 \%$ and $85 \%$ after 7 days, and by $60 \%$ and $90 \%$ after 28 day. However, the results also showed that the rate of crack healing with time was decreased irrespective of concentration of bacteria [41]. Besides, another phenomenon 
1 was observed that, healing rate was higher at higher bacterial concentrations at the early stage, while at

2 later stages, healing rate at high bacterial concentration was lower than that at low concentration (as

3 shown in Fig.10) [41]. This is mainly attributed to the fact that, under higher concentration at the initial

4 stage, as precipitation progresses, the space at the crack becomes limited, leading to slow growth of the

5 precipitation [41]. In other words, for cracks with similar width formed in the same day, healing ratio

6 will increase with time while healing rate will decrease. According to Qian et al. [63], survival numbers

7 of bacteria reduced with time due to high alkaline environment in cementitious composites. With

8 continuous cement hydration, pores in matrix decrease, then space for living bacteria decreases

9 accordingly, which eventually results in death of bacteria [63]. Decrease of pores also makes

10 transportation of oxygen and nutrients more difficult. This may be another explanation for the time effect

11 [63]. Therefore, healing ability of bacterial technology-enabled cementitious composites decreases

12 largely at later stage. Once crack occurs after a period of molding, the self-healing efficiency will

13 decrease to a large extent even if it has the same width with crack occurring immediately after molding.

\section{Applications of bacterial technology-enabled cementitious composites}

Cracks in the cementitious composites increase the risk of corrosion of the embedded steel reinforcement which could eventually leads to deterioration of materials and collapse of structures [16]. To extend the service life of structures, bacterial technology-enabled cementitious composites are used [65]. To date, there are three dominant application forms of this type of material in construction: surface treatment, self-healing material, crack healing agent $[16,35]$. It is well acknowledged that all the three application forms are based on bacterial activity. However, they present slight differences due to the different methods of applying bacteria into cementitious composites (as shown in Fig. 3).

\subsection{Surface treatment}

Cracks on surface provide paths for intrusion of water and detrimental substance which tend to cause considerable damages of structures. Therefore, surface treatment has been applied to control crack growth and increase the durability of structures. However, conventional treatments show some limitations including degradation over time, incompatible thermal expansion behavior with cementitious material and environmental pollution. Application of bacteria and nutrient solution as surface treatment agent is an effective way to overcome these drawbacks. Muynck et al. [54] found that deposition of a layer of calcite on the surface of the specimens could reduce capillary suction as well as gas permeability resulting in a more pronounced decrease in uptake of water and less pronounced change in the chromatic 
aspect, compared with the addition of mixed ureolytic cultures. Another experimental investigation conducted by Muynck et al. [58] showed that the decrease of water absorption was dependent on the porosity of specimens to some extent and an increased resistance towards freezing and thawing circle was also noticed. Qian et al. [21] investigated the crack-healing ability of surface treatment through different methods and the results also confirmed the reduction of capillary suction and excellent repair effect to small cracks at early ages (as shown in Table 7). Joshi et al. $[49,50]$ indicated that specimens with the surface treatment of solution containing bacteria and nutrients had a better performance of durability than specimens admixed with bacteria from the perspectives of water permeability and chloride permeability.

\subsection{Self-healing material}

Bacterial technology-enabled cementitious composites can act as a self-healing material (as shown in Fig. 3(b)). Bacteria are introduced into cementitious composites during casting, and when the cracks occur, water and oxygen penetrate through cracks and contact with bacteria in crack space. Then, bacterial induced calcium carbonate precipitation will fill the crack automatically [21, 66]. In general, the selfhealing efficiency can be evaluated by observing the width and the depth of healed cracks in pre-cracked specimens, or the healed area to crack area ratio.

According to Section 2.1, self-healing efficiency varies with different bacterial activities and working environment. Bacteria concentration also plays a key role in self-healing efficiency (as shown in Fig. 9). Researches about influence of crack width and crack age on self-healing ability are summarized in Table 8. It can be seen that the self-healing ability is reduced with the increase of cracking age and crack width. In addition, curing condition makes a difference on crack healing ability. Wang et al. [67] investigated self-healing efficiency of specimen with encapsulate bacterial spores in five curing environment, (a) $20{ }^{\circ} \mathrm{C},>95 \%$ relative humidity (RH); (b) immersion in water; (c) immersion in the deposition medium (DM) which consist of $0.2 \mathrm{M}$ urea and $\left.0.2 \mathrm{M} \mathrm{Ca}\left(\mathrm{NO}_{3}\right)_{2}\right)$; (d) wet-dry cycles with water(the specimens were immersed in water/DM for $16 \mathrm{~h}$ and were then exposed to air for $8 \mathrm{~h}$ ); (e) wet-dry cycles with DM. Wet-dry cycles were found to best stimulate self-healing in mortar specimens with encapsulated bacteria, and no self-healing was observed in all specimens stored at $95 \% \mathrm{RH}$, which indicated that the presence of liquid water is essential to realize self-healing ability [67]. In similar experiment conducted by Luo et al. [68], crack healing was observed in specimens under water curing and wet-dry curing while no obvious healing was observed in specimens under wet curing way. It can be concluded from the above 
1 findings that liquid water is vital to realize self-healing ability. Suleiman et al. [69] studied the self-

2 healing ability of cementitious composites with bacteria under different environmental exposure for one

3 year. One set of specimens was fully submerged in distilled water at a constant temperature of T $=19^{\circ} \mathrm{C}$,

4 while the other was exposed to the condition in both cyclic temperature and cyclic relative humidity [69].

5 The results showed that no crack healing was observed in specimens exposed to the latter condition,

6 while the crack of specimens cured in water was completely filled [69]. High crack healing efficiency of

7 bacterial technology-enabled cementitious composites can be achieved, but it only occurs in water curing

8 in laboratory instead of in real condition [69]. Additionally, there are some researches verifying the

9 possible application of bacterial technology-enabled cementitious composites to marine infrastructure.

10 Palin et al. [70] studied bacterial technology-enabled cementitious composites with bacteria encapsulated

11 in bead for possible marine applications. The bead which had the swelling and bacterial precipitation capabilities presented considerable crack healing potential. Another research investigation conducted by

13 Palin et al. [71] reported, magnesium acetate, saccharin sodium, gum Arabic, and magnesium lactate could be promising nutrients for bacteria because they are cheap and effective. According to Bansal et al. [72], a kind of halophilic bacteria named Exiguobacterium mexicanum could, under 5\% salt stress condition, precipitate calcium carbonate, increase compressive strength by $23.5 \%$, and result in a fivefold reduction in water absorption, therefore presenting excellent crack healing ability in marine environment.

Except for automatically self-healing of cracks, bacterial precipitation will prevent early-stage crack efficiently and result in denser microstructure to prolong the lifespan of concrete structures.

\subsection{Crack repairment}

21 Solution of bacteria and nutrients can act as a healing agent to repair cracked structures. Conventional healing agent shows some limitations including degradation over time, incompatible thermal expansion behavior with specimen and environmental pollution [16]. Bacterial technology-enabled cementitious composites can overcome these drawbacks effectively, by applying bacteria and nutrients solution in cracking area to precipitate calcium carbonate which fills the crack. Kalhori et al. [73] indicated that shotcrete specimens with $0.2 \mathrm{~mm}$ width crack was fully mended in the solution of bacteria, urea, and

$27 \mathrm{CaCl}_{2}$. Tittelboom et al. [26] made a comparison of repairment efficiency between bacterial solution immobilized in silica gel and traditional healing agent such as epoxy. Fig.5(a) shows the results of relative change in transmission time before and after treatment of the cracks in ultrasonic test, and it can be seen that crack treatment with B. sphaericus, immobilized in silica gel, can repair crack efficiently [26]. Fig. 
15 (b) shows TGA results for different crack repair materials containing active or autoclaved bacteria. It

can be seen that only active bacteria are able to precipitate $\mathrm{CaCO}_{3}$ crystals in the gel matrix, and calcium source of $\mathrm{Ca}\left(\mathrm{CH}_{3} \mathrm{COO}\right)_{2}$ is better than $\mathrm{CaCl}_{2}$ [26]. Choi et al. [22] immersed pre-cracked cementitious composites specimens in solution of bacteria and urea, and found it was effective to decrease the permeability of the specimen with cracks width from 0.15 to $1.64 \mathrm{~mm}$. They also observed that crack repairment was more effective for specimens with narrow cracks, and the effectiveness decreased with increasing crack width [22].

\section{Economic analysis}

\subsection{Cost}

\subsubsection{Primary cost}

Generally, the cost of bacterial technology-enabled cementitious composites is higher than that of conventional cementitious composites. Aseptic production of pure bacteria spores, nutrients, protective material and labor required contribute to the high cost $[32,74]$. In China, the price per ton of conventional cementitious composites amounts to about CNY¥ 120-200 (equivalent $\quad$ to $\$ 17.4-29$ or JPY¥ 1900-3168) [32]. An additional cost of bacteria, nutrients, protective material and manufacture procedure are estimated at CNY¥10 (\$1.5 or JPY¥159), CNY¥80 (\$11.6 or JPY¥1267), CNY¥50 (\$7.3 or JPY¥792) and around CNY¥20-30 (\$2.9-4.4 or JPY¥317-475), respectively [32]. Siddique et al. [8] indicated that bacterial technology-enabled cementitious composites with silica fume cost approximately $10 \%$ more than conventional cementitious composites with silica fume. Therefore, cost is still a major challenge for the application of bacterial technology-enabled cementitious composites.

\subsubsection{Methods to reduce cost}

Some measures have been taken to reduce the cost from several aspects such as bacteria, nutrients and manufacture process. First, low-price bacteria can be applied. Silva et al. [74] indicated that lower cost could be realized by incorporating mixed culture of ureolytic bacteria rather than pure bacteria and the enhancement of manufacture efficiency also helps reduce the cost. Zhang et al. [75] also indicated mixed bacteria can be more robust in resistance to environmental fluctuations and enhance the calcium carbonate precipitation ability, which could cut down the cost accordingly. Experiments from Williams et al. [20] showed whether bacteria were live or not, bacterial precipitation would proceed because bacteria cells could act as nucleation sites attracting calcium iron in cementitious composites. Pei et al. [19] indicated that bacterial cell walls of Bacillus subtilis significantly increased compressive strength 
and decreased porosity while its dead cell did not make any contribution. These findings suggest that the proper choice of bacteria even when they are in death can reduce the cost of bacterial technology-enabled cementitious composites due to the low requirement of bacterial viability. Second, using efficient protective material and economical nutrient can also reduce the cost. Joshi et al. [50] reported corn steep liquor, an industrial by-product, could act as an alternate nutrient to develop low-cost and environmentfriendly technology in future. Charpe et al. [28] explored the possibility of utilizing local soil bacteria in bacterial technology-enabled cementitious composites with lentil seed powder as protein source and sugar as a carbon source, because the cost of lentil seeds was around 53 times lower than that of peptone and the cost of sugar was around 12 times lower than that of D-glucose. Calcium sulphoaluminate cement, which is a type of low-alkali, fast hardening cementitious composites, is proved to be more facile and efficient as protective material, making bacterial technology enabled cementitious composite readily applicable in practice and in possession of relative low cost [32]. Limestone powder as protective material was also studied [76]. In research conducted by Shaheen et al. [76], B. subtilis was immobilized in limestone powder (LSP) before added into cementitious composites, and an enhancement of compressive strength by $5.75 \%$ at 14 days compared with specimen without bacteria was observed. Shaheen et al. [76] indicated that LSP was a promising protective material for B. subtilis ensuring its longer viability in highly alkaline environment. What is more, bacterial technology-enabled geopolymer composites with direct incorporation of bacteria have also been developed to reduce the mixing cost due to high viability of bacteria in geopolymer matrix [25]. Table 9 shows the recent researches on various methods having potential to reduce the cost of bacterial technology-enabled cementitious composites.

\subsection{Benefit to cost ratio}

Early age formation of cracks in cementitious composites structures affects the serviceability to a large extent, leading to high cost of maintenance [77]. Reduction in porosity of structures due to bacterial induced calcium carbonate precipitation brings about the reduction of permeability and the enhancement of compressive strength [11]. Besides, good compatibility between bacterial precipitation and cementitious materials and favorable thermal expansion are the other advantages of this type of materials [11]. Although the total cost of bacterial technology-enabled cementitious composite is expensive, added value in the long run should be considered [32]. As indicated by Siddique et al. [8], benefit to cost ratio is a more accurate index to evaluate the cost. In the analysis of Siddique et al. [78], the primary cost is initially estimated. Then, the benefit of specific property is calculated as the product of improvement 
1 percentage with weightage factor of 10, where the weightage factor shows the importance of a specific

2 property. Finally, the benefits to cost ratio is the ratio of sum of benefits for compressive strength,

3 permeability, water porosity and water absorption divided by its primary cost. As listed in Table 10,

4 bacterial technology-enabled cementitious composites have a relatively low cost in the long run [78].

5 Porter et al. [44] also indicated bacterial precipitation benefits in road bases due to reduction of cement

6 consumption, improving both economic and environmental sustainability. Thus, in the long term,

7 bacterial technology-enabled cementitious composite is likely to be a cost-saving construction material.

8 6. Summary and Future Opportunities

9 Bacterial technology-enabled cementitious composites have a promising future from three aspects: engineering applications, environmental protection and economic savings. Bacterial technology-enabled

11 cementitious composites can provide a smart material for surface treatment, self-healing materials and crack repairment, and has the potential to be applied to roads, tunnels and large infrastructures to enhance

13 their durability and mechanical properties. Bacterial technology-enabled cementitious composites can reduce the cement used in later maintenance and its utilization as healing agent for crack repair will minimize environmental problems. Besides, it can effectively prolong the lifespan of structures.

Despite of the merits of Bacterial technology-enabled cementitious composites, there are still some key issues remaining unaddressed. Nutrients should be further studied to find an effective multiple nutrients system to enhance the efficiency of bacterial precipitation, since a proper combination of low-cost nutrients will cut down the total cost of bacterial technology-enabled cementitious composites. Curing type and different environment exposure significantly impose restrictions on the healing-ability. Further research should be aimed at bridging the gap between experiments and practical engineering to put this type of material into practice, which can be started with developing bacteria that can survive in harsh environment. What is more, shrinkage of matrix, corrosion of steel reinforcement, sulfate attack and carbonation properties of bacterial technology-enabled cementitious materials are yet to be studied in detail.

Regardless of the aforementioned challenges, bacterial technology-enabled cementitious composites are envisioned to provide safer, more sustainable, more long-standing and more economical construction materials.

\section{Acknowledgement}

30 The authors thank the funding supported from the National Science Foundation of China (51578110) and 
1 the Fundamental Research Funds for the Central Universities in China (DUT18GJ203). 


\section{References:}

[1] Kumar V R, Bhuvaneshwari B and Maheswaran S, et al. An overview of techniques based on biomimetics for sustainable development of concrete. Current Science. 2011, 101(6): 741-747.

[2] Han N and Xing F. A comprehensive review of the study and development of microcapsule based Self-Resilience systems for concrete structures at shenzhen university. Materials. 2017, 10(1): 2.

[3] Lee Y S and Park W. Current challenges and future directions for bacterial self-healing concrete. Applied Microbiology and Biotechnology. 2018, 102(7): 3059-3070.

[4] Wang J Y, Snoeck D and Van Vlierberghe S, et al. Application of hydrogel encapsulated carbonate precipitating bacteria for approaching a realistic self-healing in concrete. Construction and Building Materials. 2014, 68: 110-119.

[5] Jonkers H M, Thijssen A and Muyzer G, et al. Application of bacteria as self-healing agent for the development of sustainable concrete. Ecological Engineering. 2010, 36(2): 230-235.

[6] Achal V, Mukherjee A and Reddy M S. Microbial concrete: Way to enhance the durability of building structures. Journal of Materials in Civil Engineering. 2011, 23(6): 730-734.

[7] Siddique R, Singh K and Kunal, et al. Properties of bacterial rice husk ash concrete. Construction and Building Materials. 2016, 121: 112-119.

[8] Siddique R, Kunal V N and Kadri E, et al. Influence of bacteria on compressive strength and permeation properties of concrete made with cement baghouse filter dust. Construction and Building Materials. 2016,106: 461-469.

[9] Vekariya M S and Pitroda J. Bacterial concrete: New Era for Construction Industry. International Journal of Engineering Trends and Technology. 2013, 4(9): 4128-4137.

[10] Kim H K, Park S J and Han J I, et al. Microbially mediated calcium carbonate precipitation on normal and lightweight concrete. Construction and Building Materials. 2013, 38: 1073-1082.

[11] Seifan M, Samani A K, and Berenjian A. Bioconcrete: Next generation of self-healing concrete. Applied Microbiology and Biotechnology, 2016, 100(6): 2591-2602.

[12] $\mathrm{Wu}$ M, Johannesson B and Geiker M. A review: Self-healing in cementitious materials and engineered cementitious composite as a self-healing material. Construction and Building Materials. 2012, 28(1): 571-583.

[13] Kadapure S A, Kulkarni G S and Prakash K B. A laboratory investigation on the production of sustainable Bacteria-Blended fly ash concrete. Arabian Journal for Science and Engineering. 2017, 42(3): 
1039-1048.

[14] De Belie N and Wang J. Bacteria-based repair and self-healing of concrete. Journal of Sustainable Cement-Based Materials. 2016, 5(1-2): 35-56.

[15] Wang C L. Experimental study on microbial remediation of concrete cracks. Dissertation for the Master of Science in Water Conservancy and Hydropower Engineering. Tianjin University, China. 2016.

[16] Siddique R and Chahal N K. Effect of ureolytic bacteria on concrete properties. Construction and Building Materials. 2011, 25(10): 3791-3801.

[17] Ersan Y C, Silva F B D and Boon N, et al. Screening of bacteria and concrete compatible protection materials. Construction and Building Materials. 2015, 88: 196-203

[18] De Muynck W, De Belie N and Verstraete W. Microbial carbonate precipitation in construction materials: A review. Ecological Engineering. 2010, 36(2): 118-136.

[19] Pei R, Liu J and Wang S, et al. Use of bacterial cell walls to improve the mechanical performance of concrete. Cement and Concrete Composites. 2013, 39: 122-130.

[20] Williams S L, Kirisits M J and Ferron R D. Influence of concrete-related environmental stressors on biomineralizing bacteria used in self-healing concrete. Construction and Building Materials. 2017, 139: $611-618$

[21] Qian C X, Luo M and Ren L F, et al. Self-Healing and repairing concrete cracks based on biomineralization. Key Engineering Materials. 2014, 629-630: 494-503.

[22] Choi S, Wang K and Wen Z, et al. Mortar crack repair using microbial induced calcite precipitation method. Cement and Concrete Composites. 2017, 83: 209-221.

[23] Sangadji S, Wiktor V and Jonkers H M, et al. The Use of alkaliphilic bacteria-based repair solution for porous network concrete healing mechanism. Procedia Engineering. 2017, 171: 606-613.

[24] Ghosh P, Mandal S and Chattopadhyay B D, et al. Use of microorganism to improve the strength of cement mortar. Cement and Concrete Research. 2005, 35(10): 1980-1983.

[25] Jadhav U U, Lahoti M and Chen Z, et al. Viability of bacterial spores and crack healing in bacteriacontaining geopolymer. Construction and Building Materials. 2018, 169: 716-723

[26] Van Tittelboom K, De Belie N and De Muynck W, et al. Use of bacteria to repair cracks in concrete. Cement and Concrete Research. 2010, 40(1): 157-166.

[27] Khaliq W and Ehsan M B. Crack healing in concrete using various bio influenced self-healing techniques. Construction and Building Materials. 2016, 102: 349-357. 
[28] Charpe A U, Latkar M V and Chakrabarti T. Microbially assisted cementation - a biotechnological approach to improve mechanical properties of cement. Construction and Building Materials. 2017, 135: $472-476$.

[29] Xu J, X. Wang, B. Wang. Biochemical process of ureolysis-based microbial $\mathrm{CaCO}_{3}$ precipitation and its application in self-healing concrete. Applied Microbiology and Biotechnology. 2018, 102(7): $3121-3132$.

[30]. Xu J, Wang X and Zuo J, et al. Self-Healing of concrete cracks by ceramsite-loaded microorganisms. Advances in Materials Science and Engineering. 2018, 1-8.

[31] Bundur Z B, Kirisits M J and Ferron R D. Use of pre-wetted lightweight fine expanded shale aggregates as internal nutrient reservoirs for microorganisms in bio-mineralized mortar. Cement and Concrete Composites. 2017, 84: 167-174.

[32] $\mathrm{Xu} \mathrm{J}$ and Wang X. Self-healing of concrete cracks by use of bacteria-containing low alkali cementitious material. Construction and Building Materials. 2018, 167: 1-14.

[33] Seifan M, Sarmah A K and Samani A K, et al. Mechanical properties of bio self-healing concrete containing immobilized bacteria with iron oxide nanoparticles. Applied Microbiology and Biotechnology. 2018, 102(10): 4489-4498.

[34] Manzur A, Rahman F and Afroz S, et al. Potential of a microbiologically induced calcite precipitation process for durability enhancement of masonry aggregate concrete. Journal of Materials in Civil. 2017, 29(5): 1-12

[35] De Belie N. Application of bacteria in concrete: A critical evaluation of the current status. RILEM Technical Letters. 2016, 1: 56-61.

[36] Vijay K, Murmu M and Deo S V. Bacteria based self-healing concrete - a review. Construction and Building Materials. 2017, 152: 1008-1014.

[37] Wang J, Van Tittelboom K and De Belie N, et al. Use of silica gel or polyurethane immobilized bacteria for self-healing concrete. Construction and Building Materials. 2012, 26(1): 532-540.

[38] Bhaskar S, Anwar Hossain K M and Lachemi M, et al. Effect of self-healing on strength and durability of zeolite-immobilized bacterial cementitious mortar composites. Cement and Concrete Composites. 2017, 82: 23-33.

[39] Zhang Y, Guo H X, and Cheng X H. Role of calcium sources in the strength and microstructure of microbial mortar. Construction and Building Materials. 2015, 77: 160-167. 
[40] Amiri A, Bundur Z B. Use of corn-steep liquor as an alternative carbon source for biomineralization in cement-based materials and its impact on performance. Construction and Building Materials, 2018, 165: 655-662.

[41] Mondal S and Ghosh A D. Investigation into the optimal bacterial concentration for compressive strength enhancement of microbial concrete. Construction and Building Materials. 2018, 183: 202-214. [42] Andalib R, Abd Majid M Z and Hussin M W, et al. Optimum concentration of Bacillus megaterium for strengthening structural concrete. Construction and Building Materials. 2016, 118: 180-193.

[43] Rao M V S, Reddy V S and Sasikala C. Performance of microbial concrete developed using bacillus subtilus JC3. Journal of the Institution of Engineers (India): Series A. 2017, 98(4): 501-510.

[44] Porter H, Dhami N K and Mukherjee A. Sustainable road bases with microbial precipitation. Proceedings of the Institution of Civil Engineers - Construction Materials. 2018, 171(3): 95-108.

[45] Chahal N and Siddique R. Permeation properties of concrete made with fly ash and silica fume: Influence of ureolytic bacteria. Construction and Building Materials. 2013, 49: 161-174.

[46] Qian C, Yu X, Wang X. Potential uses and cementing mechanism of bio-carbonate cement and biophosphate cement. AIP Advances, 2018, 8(9): 095224.

[47] Jagannathan P, Narayanana K S S and Arunachalamb K D, et al. Studies on the mechanical properties of bacterial concrete with two bacterial species. Materials Today. 2017, 5: 8875-8879.

[48] Chahal N, Siddique R, and Rajor A. Influence of bacteria on the compressive strength, water absorption and rapid chloride permeability of fly ash concrete. Construction and Building Materials. 2012, 28(1): 351-356.

[49] Joshi S, Goyal S and Reddy M S. Influence of nutrient components of media on structural properties of concrete during biocementation. Construction and Building Materials. 2018, 158: 601-613.

[50] Joshi S, Goyal S and Reddy M S. Corn steep liquor as a nutritional source for biocementation and its impact on concrete structural properties. Journal of Industrial Microbiology and Biotechnology. 2018, 45(8): 657-667.

[51] Irwan J M, Anneza L H and Othman N, et al. Mechanical properties of concrete with enterococcus faecalis and calcium lactate. Procedia Engineering. 2017, 171: 592-597.

[52] Thiyagarajan H, Maheswaran S and Mapa M, et al. Investigation of bacterial activity on compressive strength of cement mortar in different curing media. Journal of Advanced Concrete Technology. 2016, 14: $125-133$. 
[53] Alazhari M, Sharma T, and Heath A, et al. Application of expanded perlite encapsulated bacteria and growth media for self-healing concrete. Construction and Building Materials. 2018, 160: 610-619.

[54] De Muynck W, Cox K and Belie N D, et al. Bacterial carbonate precipitation as an alternative surface treatment for concrete. Construction and Building Materials. 2008, 22(5): 875-885.

[55] Zhang J, Mai B and Cai T, et al. Optimization of a binary concrete crack self-healing system containing bacteria and oxygen. Materials. 2017, 10(2): 116.

[56] Bashir J, IfrahKathwari and Tiwary A, et al. Bio concrete-the self-healing concrete. Indian Journal of Science and Technology. 2016, 9(47): 1-5.

[57] Achal V, Mukerjee A and Reddy M S. Biogenic treatment improves the durability and remediates the cracks of concrete structures. Construction and Building Materials. 2013, 48: 1-5.

[58] De Muynck W, Debrouwer D and De Belie N, et al. Bacterial carbonate precipitation improves the durability of cementitious materials. Cement and Concrete Research. 2008, 38(7): 1005-1014.

[59] Irwan J M, Anneza L H and Othman N, et al. Calcium lactate addition in bioconcrete: Effect on compressive strength and water penetration. MATEC Web of Conferences, EDP Sciences. 2016, 78: 01027.

[60] Ling H and Qian C. Effects of self-healing cracks in bacterial concrete on the transmission of chloride during electromigration. Construction and Building Materials. 2017, 144: 406-411.

[61] Chahal N, Siddique R and Rajor A. Influence of bacteria on the compressive strength, water absorption and rapid chloride permeability of concrete incorporating silica fume. Construction and Building Materials. 2012, 37: 645-651.

[62] Tayebani B, Mostofinejad D. Penetrability, corrosion potential, and electrical resistivity of bacterial concrete. Journal of Materials in Civil Engineering, 2019, 31(3): 04019002.

[63] Qian C, Chen H and Ren L, et al. Self-healing of early age cracks in cement-based materials by mineralization of carbonic anhydrase microorganism. Frontiers in Microbiology. 2015, 6: 1225

[64] Wiktor, V. and H.M. Jonkers, Quantification of crack-healing in novel bacteria-based self-healing concrete. Cement and Concrete Composites, 2011. 33(7): 763-770.

[65] Muhammad N Z, Shafaghat A and Keyvanfar A, et al. Tests and methods of evaluating the selfhealing efficiency of concrete: A review. Construction and Building Materials. 2016, 112: 1123-1132.

[66] Luo M and Qian C. Influences of bacteria-based self-healing agents on cementitious materials hydration kinetics and compressive strength. Construction and Building Materials. 2016, 121: 659-663. 
[67] Wang J Y, Soens H and Verstraete W, et al. Self-healing concrete by use of microencapsulated bacterial spores. Cement and Concrete Research. 2014, 56: 139-152.

[68] Luo M, Qian C and Li R. Factors affecting crack repairing capacity of bacteria-based self-healing concrete. Construction and Building Materials. 2015, 87: 1-7.

[69] Suleiman A R and Nehdi M L. Effect of environmental exposure on autogenous self-healing of cracked cement-based materials. Cement and Concrete Research. 2018, 111: 197-208.

[70] Palin D, Wiktor V and Jonkers H M. A bacteria-based bead for possible self-healing marine concrete applications. Smart Materials and Structures. 2016, 25(8): 84008.

[71] Palin D, Wiktor V and Jonkers H M. Towards cost efficient bacteria based self-healing marine concrete. Concrete Solutions; CRC Press, Taylor Francis Group: Boca Raton, Leiden, London, New York. 2014: 105-108.

[72] Bansal R, Dhami N K and Mukherjee A, et al. Biocalcification by halophilic bacteria for remediation of concrete structures in marine environment. Journal of Industrial Microbiology \& Biotechnology. 2016, 43(11): 1497-1505.

[73] Kalhori $\mathrm{H}$ and Bagherpour R. Application of carbonate precipitating bacteria for improving properties and repairing cracks of shotcrete. Construction and Building Materials. 2017, 148: 249-260.

[74] Silva F B, Boon N and De Belie N, et al. Industrial application of biological self-healing concrete: Challenges and economical feasibility. Journal of Commercial Biotechnology. 2015, 21(1): 31-38.

[75] Zhang J, Zhou A, and Liu Y, et al. Microbial network of the carbonate precipitation process induced by microbial consortia and the potential application to crack healing in concrete. Scientific Reports. 2017, $7(1): 1-10$

[76] Shaheen N, Khushnood R A and Ud Din S. Bioimmobilized limestone powder for autonomous healing of cementitious systems: A feasibility study. Advances in Materials Science and Engineering. 2018, 1-9.

[77] Joshi S, Goyal S and Mukherjee A, et al. Microbial healing of cracks in concrete: A review. Journal of Industrial Microbiology \& Biotechnology. 2017, 44(11): 1511-1525.

[78] Siddique R, Jameel A and Singh M, et al. Effect of bacteria on strength, permeation characteristics and micro-structure of silica fume concrete. Construction and Building Materials. 2017, 142: 92-100. [79] Jonkers H M. Self-healing concrete: a biological approach. Book: Self-Healing Materials, Publisher: Springer, Editors: S. van der Zwaag. 2007: 195-204. 
[80] White S R, Sottos N R and Geubelle P H, et al. Autonomic healing of polymer composites. Letters to Nature. 2001, 409: 794-797.

[81] Achal V, Pan X and Özyurt N. Improved strength and durability of fly ash-amended concrete by microbial calcite precipitation. Ecological Engineering. 2011, 37(4): 554-559.

[82] Kim G, Kim J and Youn H. Effect of temperature, $\mathrm{pH}$, and reaction duration on microbially induced calcite precipitation. Applied Sciences. 2018, 8(8): 1277.

[83] Vashisht R, Attri S and Sharma D, et al. Monitoring biocalcification potential of Lysinibacillus sp. isolated from alluvial soils for improved compressive strength of concrete. Microbiological Research. 2018, 207: 226-231.

[84] Tziviloglou E, Wiktor V and Jonkers H M, et al. Selection of nutrient used in biogenic healing agent for cementitious materials. Frontiers in Materials. 2017, 4: 15.

[85] Purwanto H A, Nugroho A, and Aprilin S R. Study of volcanic-ash-impregnated-bacteria filler to the compressive strength of concrete. MATEC Web of Conferences. 2017, 138: 01014.

[86] Sharma T K, Alazhari M, and Heath A, et al. Alkaliphilic Bacillus species show potential application in concrete crack repair by virtue of rapid spore production and germination then extracellular calcite formation. Journal of Applied Microbiology. 2017, 122(5): 1233-1244.

[87] Alshalif A F, Irwan J M and Othman N, et al. New medium for isolation of bacteria from cement kiln dust with a potential to apply in bio-concrete. IOP Conference Series: Earth and Environmental Science. 2018, 140(1): 012155.

[88] Ghosh P, Mandal S and Pal S, et al. Development of bioconcrete material using an enrichment culture of novel thermophilic anaerobic bacteria. Indian journal of experimental biology. 2006, 44(4): 336-339. 


\section{Figures}

(a)

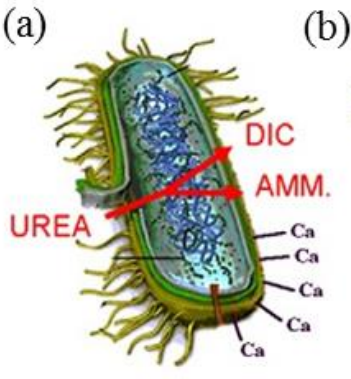

(b)

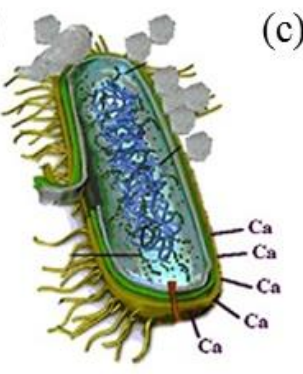

(c)

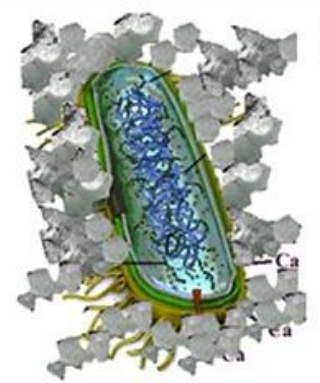

(d)

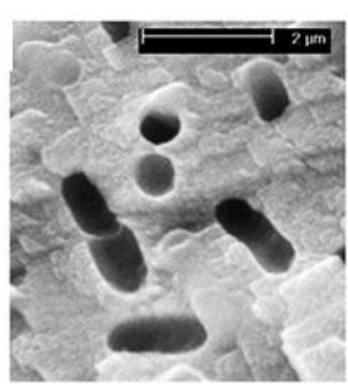

Fig. 1 Diagrams about process of the events occurring during bacterial precipitation through urea hydrolysis: (a) calcium ions was attracted by bacteria, and urea was decomposed into dissolved inorganic carbon and ammonium; (b) bacterial precipitation is on the bacterial cell wall; (c) the whole cell is encapsulated by bacterial precipitation; (d) the imprints of bacterial cells in bacterial technologyenabled cementitious composites [18]
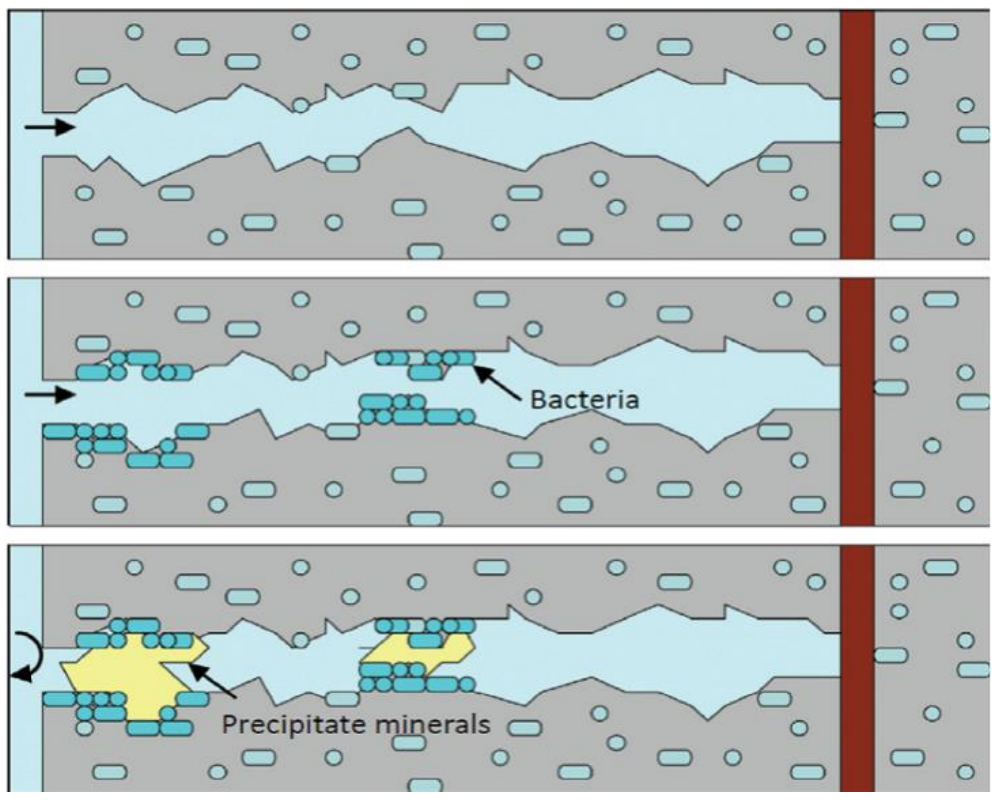

Fig. 2 Crack healing process of bacterial technology-enabled cementitious composites [79] 


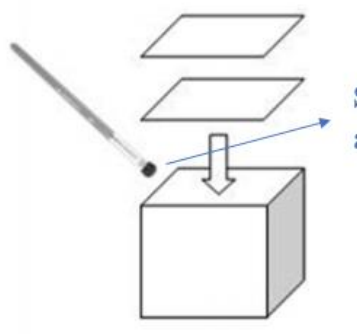

Solution of bacteria

and nutrients

Surface treatment

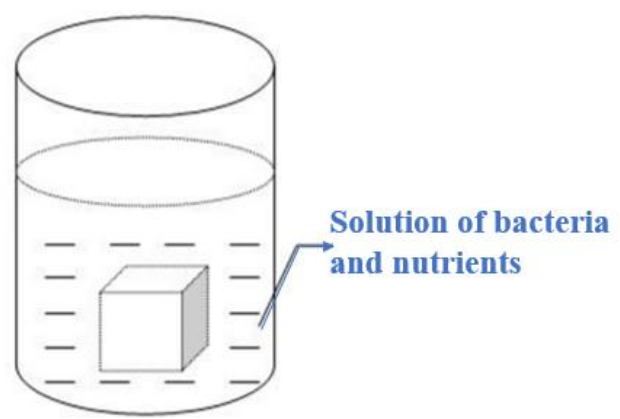

a) Surface treatment. Solution of bacteria and nutrients is applied in cementitious composites without cracks to enhance the durability by brushing (left) or immersing (right) [21].
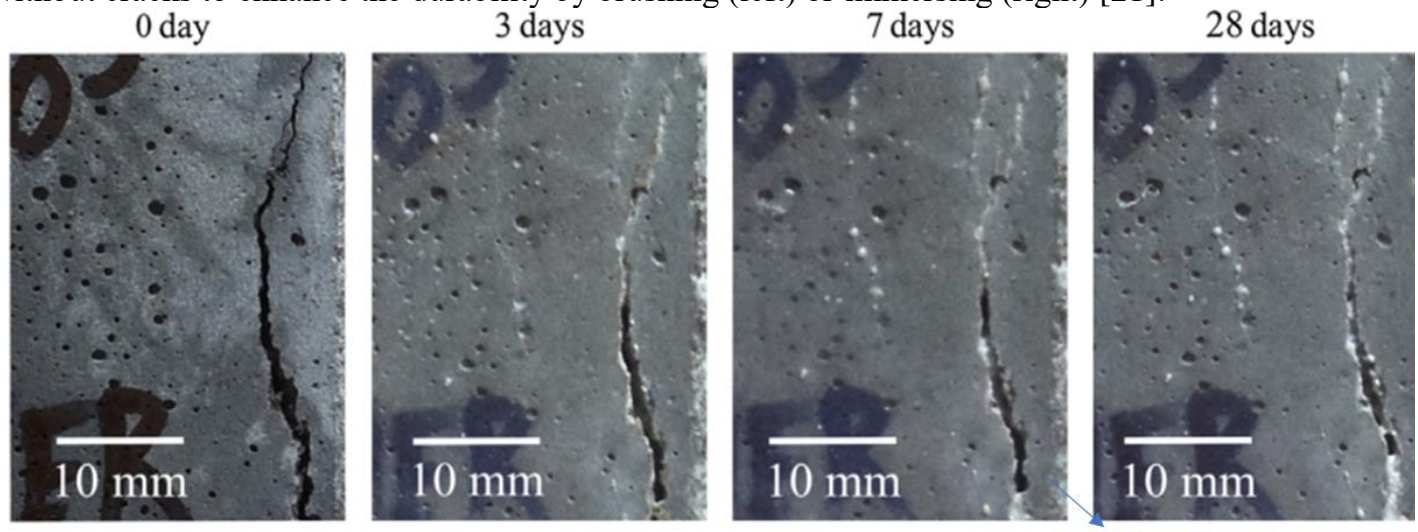

b) Self-healing material. Bacteria is added in cementitious composites by direct application, immobilization or encapsulation to heal the crack automatically, as time goes on, the crack is healed gradually.

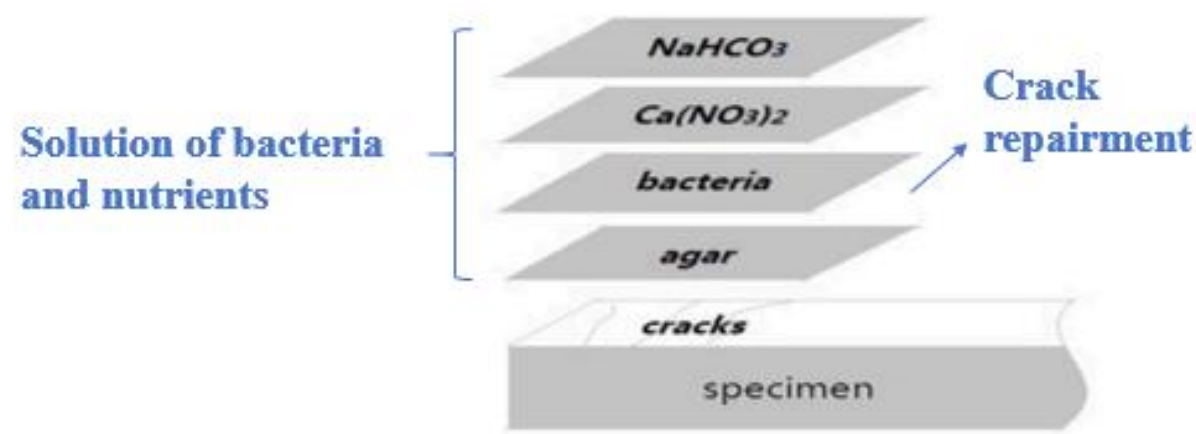

c) Crack repairment. Solution of bacteria and nutrients is applied in cementitious composites with cracks to repair broken structure [41].

Fig. 3 Schematic diagram of application of bacterial technology-enabled cementitious composites according to various methods applying bacteria into cementitious composites, a) surface treatment; b) self-healing material; c) crack repairment. 


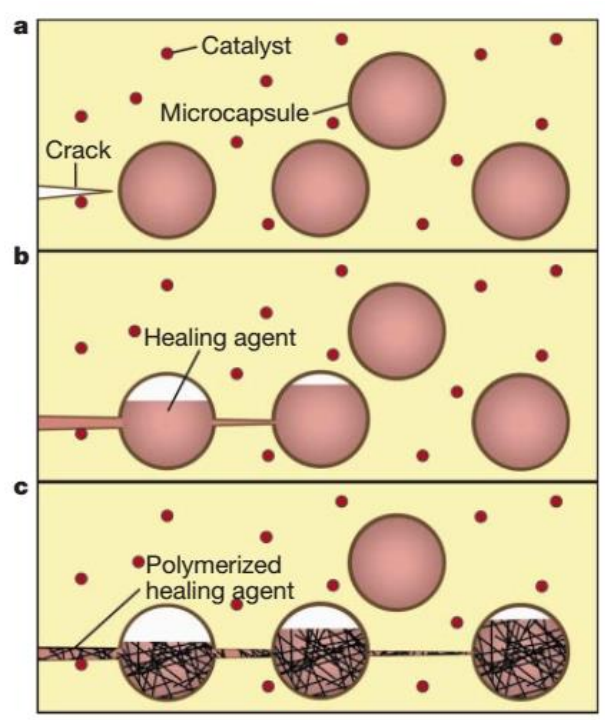

Fig. 4 Simple process of encapsulation approach: (a) formation of cracks in matrix; (b) process of releasing healing agent; (c) process of crack healing [80]
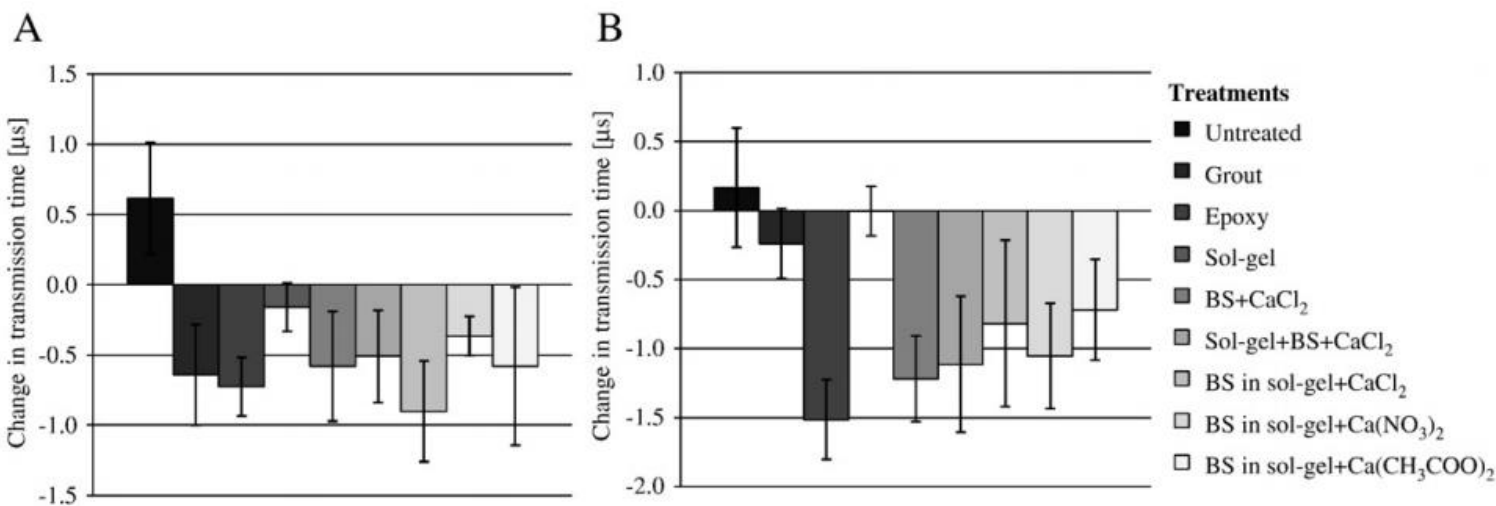

a) Relative change in transmission time before and after treatment of the cracks for a crack depth of (A) $10 \mathrm{~mm}$ and (B) $20 \mathrm{~mm}$.

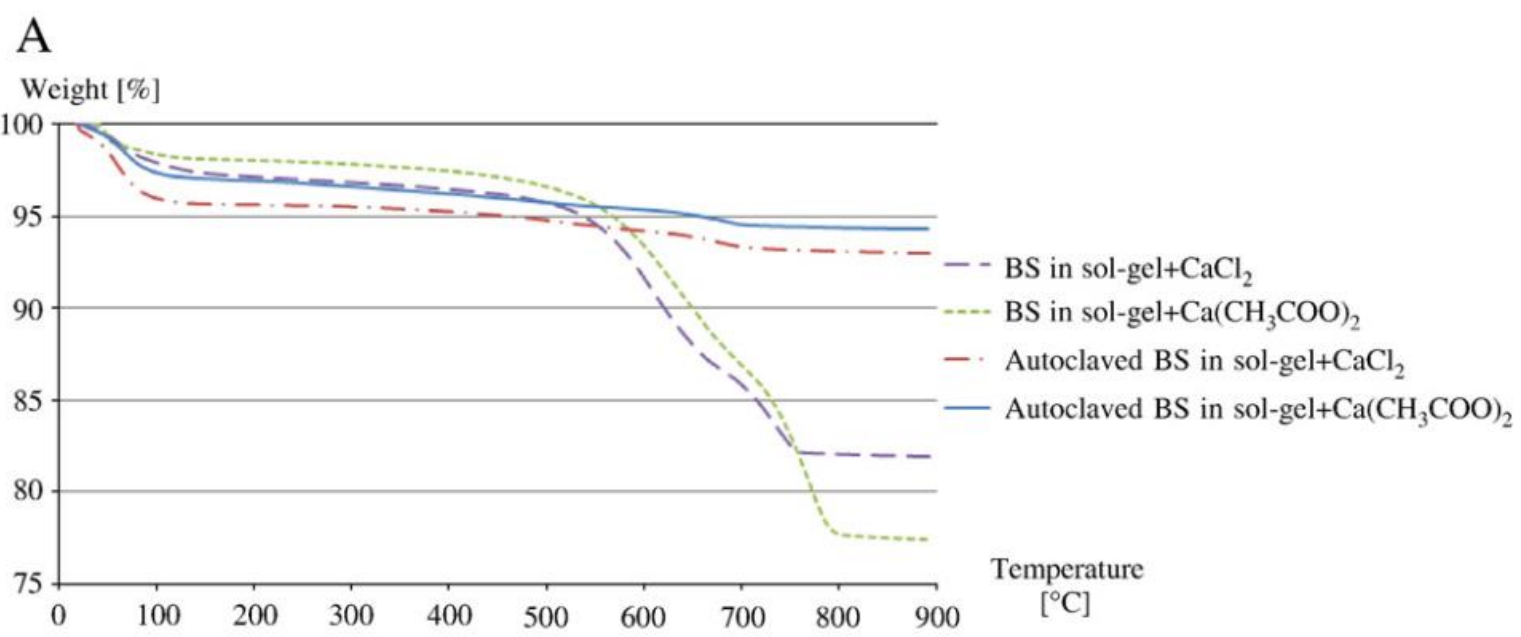




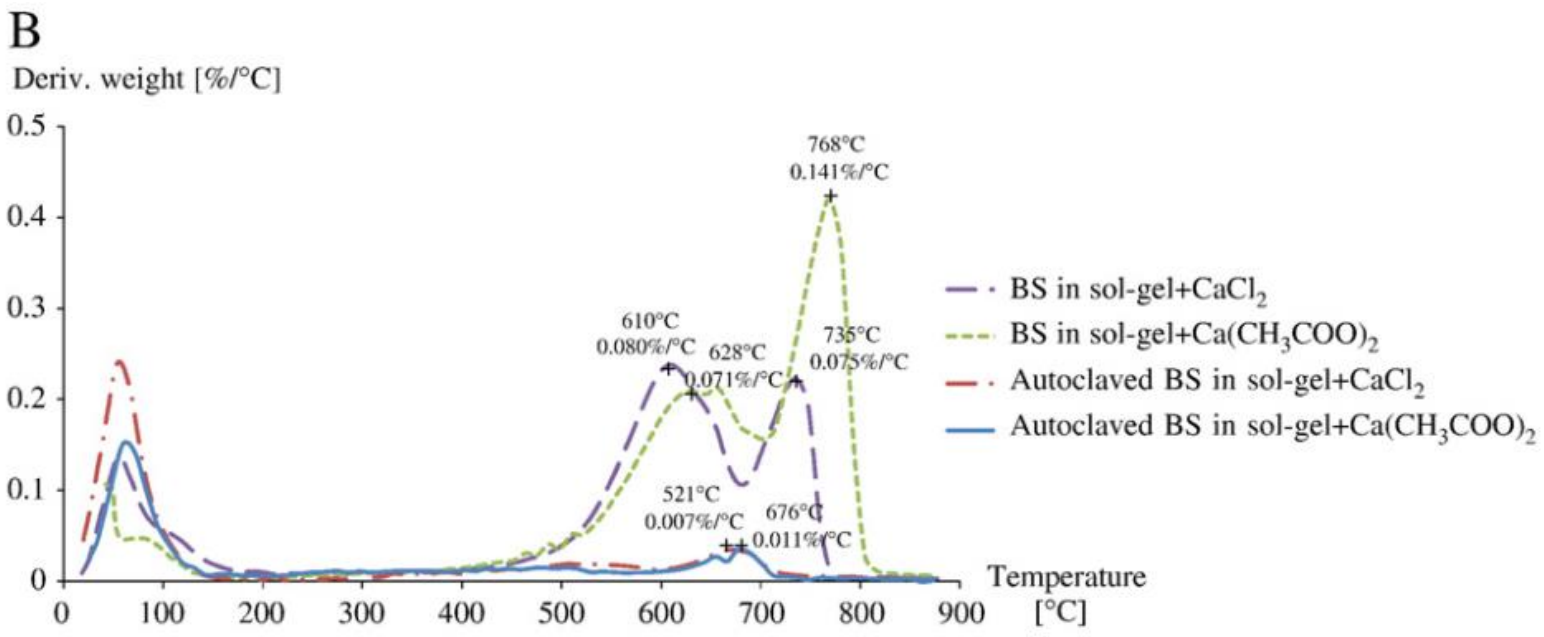

b) TGA results for different crack repair materials containing active or autoclaved bacteria, (A) decrease in weight versus temperature, and (B) derivative of weight loss versus increase in temperature Fig. 5 Repairment efficiency analysis of bacterial solution as crack healing agent by ultrasonic test and TGA analysis [26]

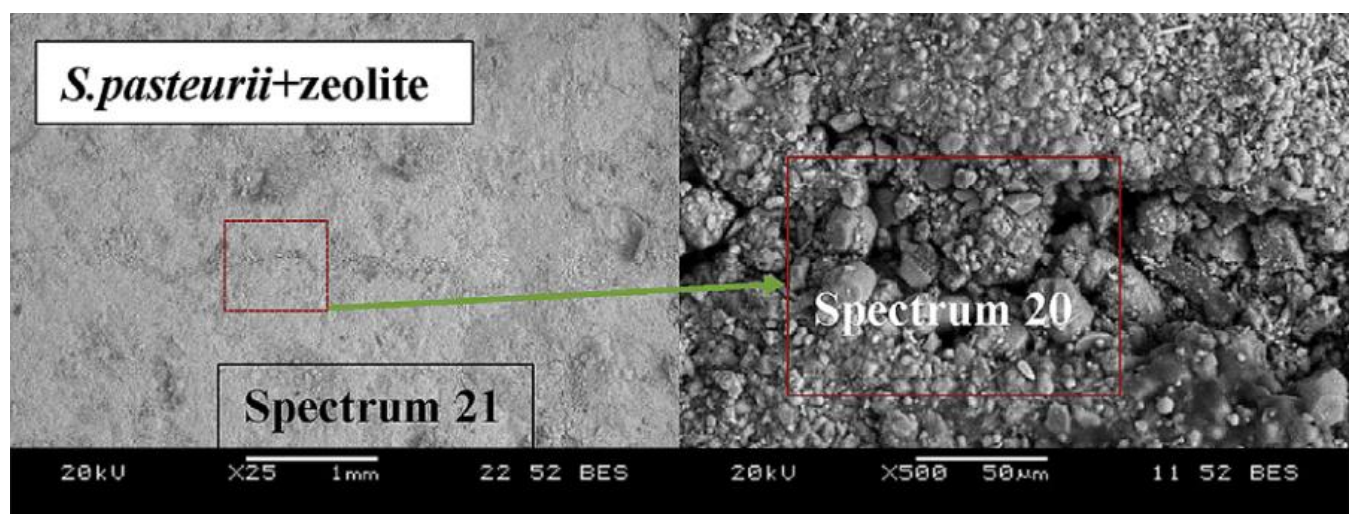

a) around $100 \mathrm{~mm}$ wide cracks were completely filled by calcite crystals produced by Sporosarcina pasteurii immobilized in zeolite

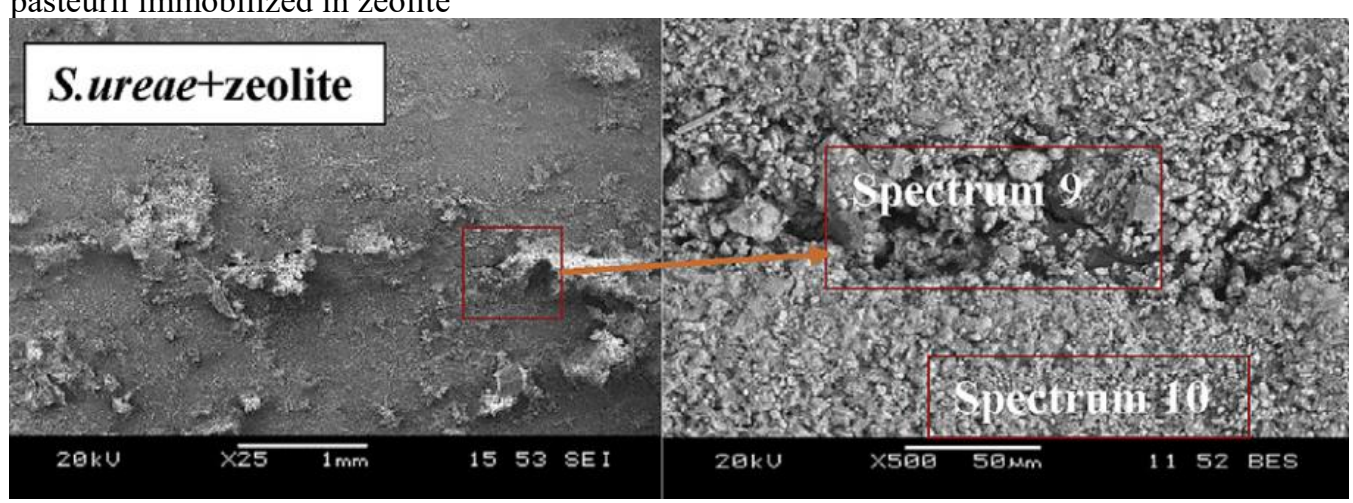

b) the $70 \mathrm{~mm}$ wide cracks were completely filled by calcite crystals produced by Sporosarcina ureae immobilized in zeolite

Fig. 6 SEM observation of the self-healing products in the crack area of specimens with Sporosarcina pasteurii and Sporosarcina ureae, distinct rhombohedral-shaped crystals were observed in the crack area in both specimens, and precipitated calcite crystals by former were denser than those formed by later [38] 


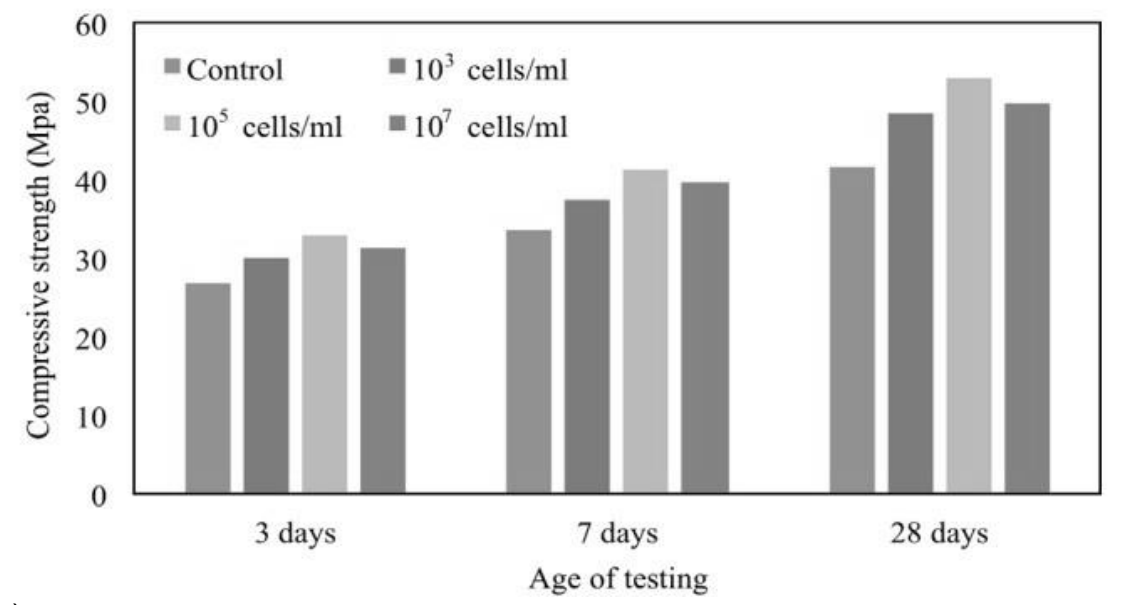

a)

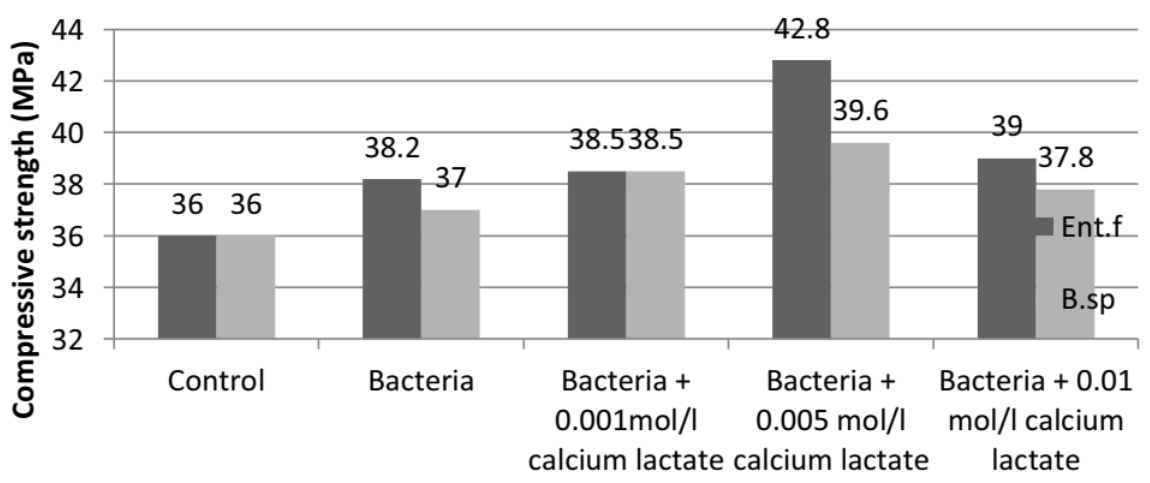

b)

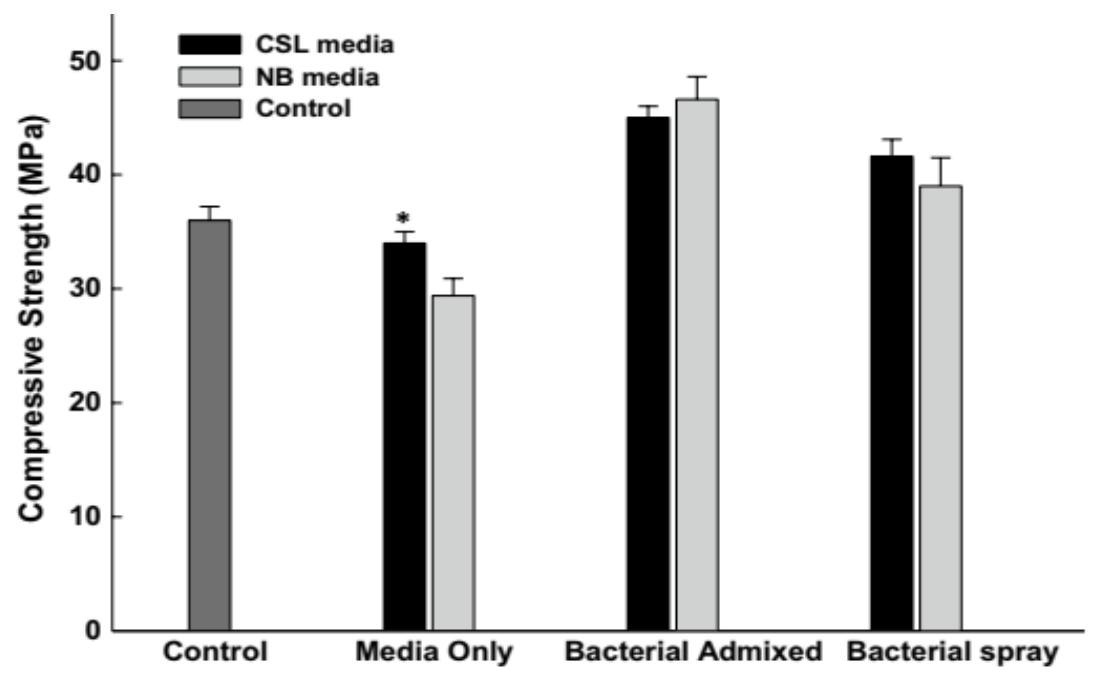

c)

Fig. 7 Compressive strength affected by a) bacteria concentration of $10^{3}, 10^{5}, 10^{7}$ cell. $\mathrm{ml}^{-1}$ [41] b) bacteria of Enterococcus faecalis and Bacillus sp and calcium lactate concentration with $0.001,0.005$, $0.01 \mathrm{~mol} \cdot \mathrm{L}^{-1}[59] \mathrm{c}$ ) nutrients of corn steep liquor and nutrient broth (NB) (Peptone $10 \mathrm{~g} \cdot \mathrm{L}^{-1}$, yeast extract $10 \mathrm{~g} \cdot \mathrm{L}^{-1}$, sodium chloride $5 \mathrm{~g} \cdot \mathrm{L}^{-1}[50]$ 


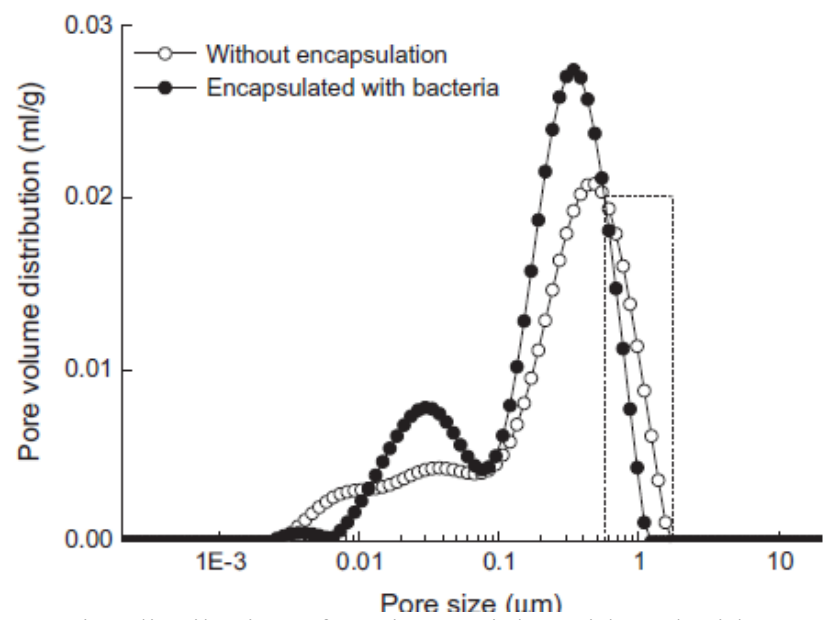

Fig. 8 Pore diameter size distribution of carrier particles with and without encapsulation [32]
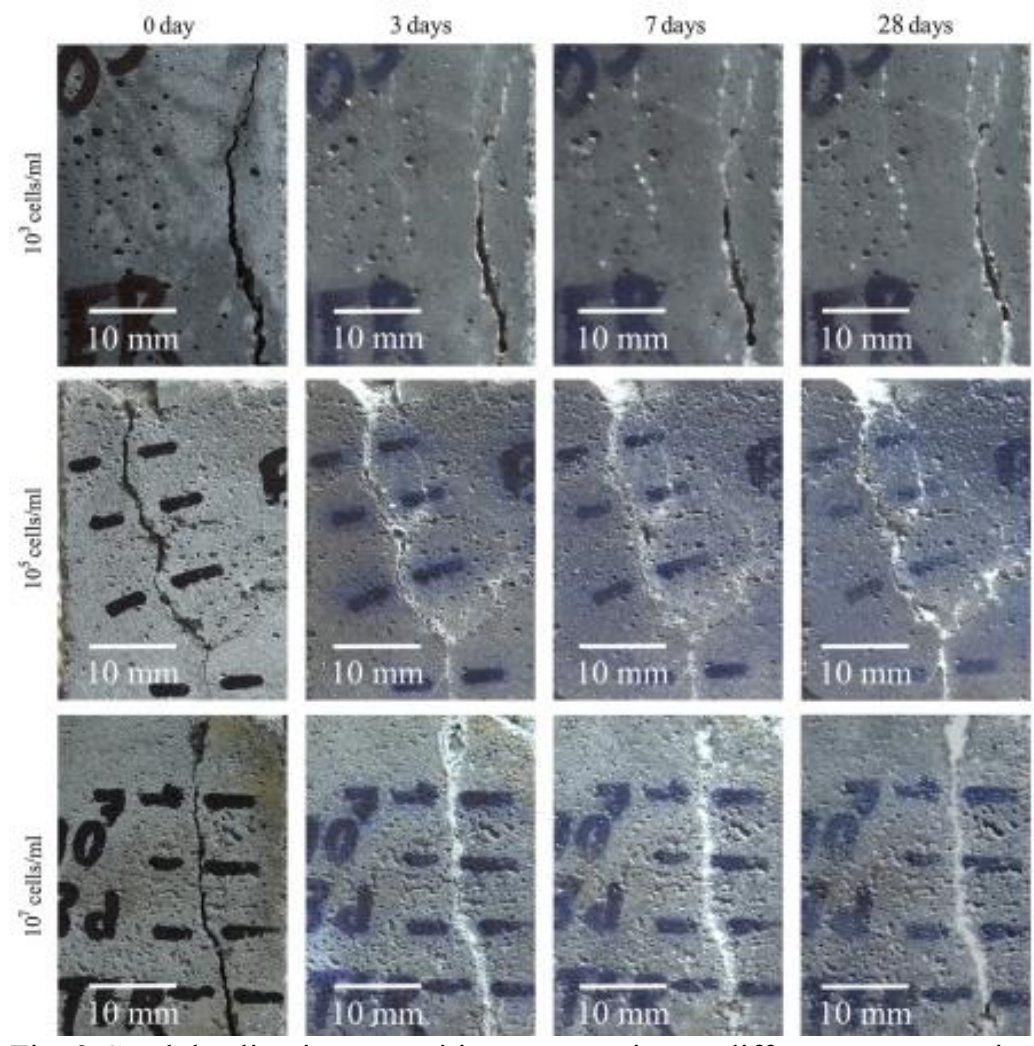

Fig. 9 Crack healing in cementitious composites at different concentrations of bacteria [41] 


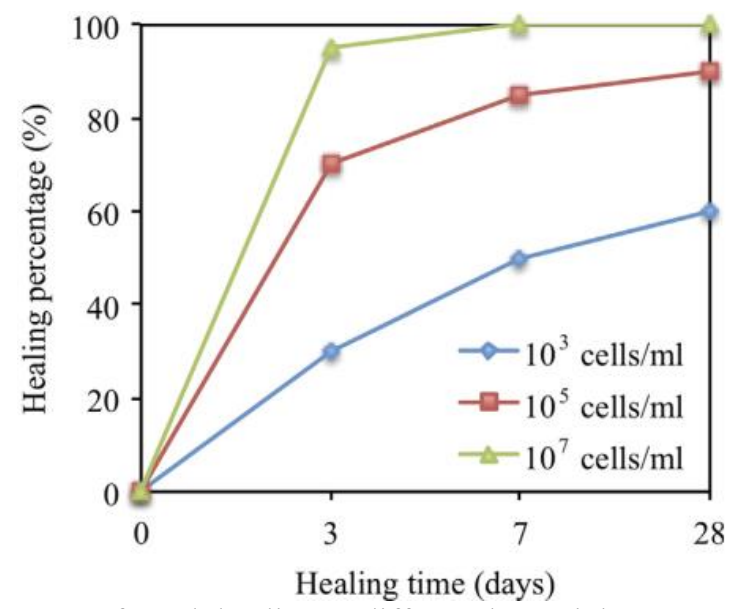

Fig.10 Rate of crack healing at different bacterial concentrations

Tables

Table 1 Different bacterial activities of bacterial calcium carbonate precipitation [14]

\begin{tabular}{|c|c|c|c|c|c|}
\hline Autotrophic bacteria & \multicolumn{5}{|c|}{ Heterotrophic bacteria } \\
\hline $\begin{array}{l}\text { Non-methylotrophic } \\
\text { methanogenesis }\end{array}$ & $\begin{array}{l}\text { Assimilatory } \\
\text { pathways }\end{array}$ & \multicolumn{4}{|c|}{ Dissimilatory pathways } \\
\hline \multirow{3}{*}{$\begin{array}{l}\text { Anoxygenic } \\
\text { photosynthesis }\end{array}$} & \multirow[t]{3}{*}{ Urea hydrolysis } & \multicolumn{4}{|c|}{ Oxidation of organic carbon } \\
\hline & & \multicolumn{2}{|c|}{ Aerobic } & \multicolumn{2}{|l|}{ Anaerobic } \\
\hline & & Process & $\begin{array}{l}\mathrm{e}^{-} \\
\text {acceptor }\end{array}$ & Process & $\mathrm{e}^{-}$acceptor \\
\hline \multirow{2}{*}{$\begin{array}{l}\text { Oxygenic } \\
\text { photosynthesis }\end{array}$} & \multirow{2}{*}{$\begin{array}{l}\text { Ammonification } \\
\text { of amino acids }\end{array}$} & Respiration & $\mathrm{O}_{2}$ & $\mathrm{NO}_{\mathrm{x}}$ reduction & $\mathrm{NO}_{3}^{-} / \mathrm{NO}_{2}^{-}$ \\
\hline & & $\begin{array}{l}\text { Methane } \\
\text { oxidation }\end{array}$ & $\mathrm{CH}_{4} / \mathrm{O}_{2}$ & $\begin{array}{l}\text { Sulfate } \\
\text { reduction }\end{array}$ & $\mathrm{SO}_{4}^{2-}$ \\
\hline
\end{tabular}


Table 2 The mechanisms of bacterial induced calcium carbonate precipitation and its characteristic with various bacterial activities

\begin{tabular}{|c|c|c|c|}
\hline Bacterial activity & Mechanism and Process $[15,16]$ & Typical Characteristic[17] & Typical bacteria \\
\hline \multirow[b]{2}{*}{ Photosynthesis } & \multirow{2}{*}{$\begin{array}{l}\mathrm{CO}_{2}+\mathrm{H}_{2} \mathrm{O} \rightarrow\left(\mathrm{CH}_{2} \mathrm{O}\right)+\mathrm{O}_{2} \\
2 \mathrm{HCO}_{3}^{-} \leftrightarrow \mathrm{CO}_{2}+\mathrm{CO}_{3}^{2-}+\mathrm{H}_{2} \mathrm{O} \leftrightarrow \\
\mathrm{CO}_{3}^{2-}+\mathrm{H}_{2} \mathrm{O} \leftrightarrow \mathrm{HCO}_{3}^{-}+\mathrm{OH}^{-} \\
\mathrm{Ca}^{2+}+\mathrm{HCO}_{3}^{-}+\mathrm{OH}^{-} \rightarrow \mathrm{CaCO}_{3}+2 \mathrm{H}_{2} \mathrm{O}\end{array}$} & Usually appearance in aquatic environment & \multirow[b]{2}{*}{--} \\
\hline & & $\mathrm{PH}$ increase due to the reduction of carbon dioxide & \\
\hline Sulfate reduction & $\begin{array}{l}\mathrm{CaSO}_{4} \cdot 2 \mathrm{H}_{2} \mathrm{O} \rightarrow \mathrm{Ca}^{2+}+\mathrm{SO}_{4}^{2-}+2 \mathrm{H}_{2} \mathrm{O} \\
2\left(\mathrm{CH}_{2} \mathrm{O}\right)+\mathrm{SO}_{4}^{2-} \rightarrow \mathrm{HS}^{-}+\mathrm{HCO}_{3}^{-}+\mathrm{CO}_{2}+\mathrm{H}_{2} \mathrm{O} \\
\mathrm{Ca}^{2+}+\mathrm{HCO}_{3}^{-}+\mathrm{OH}^{-} \rightarrow \mathrm{CaCO}_{3}+2 \mathrm{H}_{2} \mathrm{O} \\
\end{array}$ & $\begin{array}{l}\text { Capability of carbonate precipitation realization without } \\
\text { oxygen }\end{array}$ & -- \\
\hline \multirow{4}{*}{ Urea hydrolysis } & \multirow{4}{*}{$\begin{array}{l}\mathrm{CO}\left(\mathrm{NH}_{2}\right)_{2}+\mathrm{H}_{2} \mathrm{O} \rightarrow \mathrm{NH}_{2} \mathrm{COOH}+\mathrm{H}_{2} \mathrm{CO}_{3} \\
\mathrm{NH}_{2} \mathrm{COOH}+\mathrm{H}_{2} \mathrm{O} \rightarrow \mathrm{H}_{\mathrm{C}} \mathrm{CO}_{3}+\mathrm{NH}_{3} \\
\mathrm{H}_{2} \mathrm{CO}_{3} \leftrightarrow \mathrm{HCO}_{3}^{-}+\mathrm{H}^{+} \\
\mathrm{HCO}_{3}^{-}+\mathrm{H}^{+}+2 \mathrm{NH}_{4}^{+}+2 \mathrm{OH}^{-} \leftrightarrow \mathrm{CO}_{3}^{2-}+\mathrm{H}_{2} \mathrm{O}+2 \mathrm{NH}_{4}^{+} \\
\mathrm{Ca}^{2+}+\mathrm{HCO}_{3}^{-}+\mathrm{OH}^{-} \rightarrow \mathrm{CaCO}_{3}+2 \mathrm{H}_{2} \mathrm{O}\end{array}$} & Widely accepted and used & Bacillus subtilis [19] \\
\hline & & $\begin{array}{l}\text { Formation of spores against high mechanical pressure } \\
\text { and alkaline environment [24] }\end{array}$ & Bacillus megaterium [81] \\
\hline & & A high urease activity and very negative f-potential [54] & Bacillus sphaericus [54] \\
\hline & & Less sensitive to $\mathrm{pH}$ & S. saprophyticus [82] \\
\hline \multirow{2}{*}{$\begin{array}{l}\text { Denitrification } \\
\left(\mathrm{NO}_{\mathrm{x}} \text { reduction }\right)\end{array}$} & \multirow{2}{*}{$\begin{array}{l}\mathrm{CH}_{3} \mathrm{COO}^{-}+2.6 \mathrm{H}^{+}+1.6 \mathrm{NO}_{3}^{-} \rightarrow 2 \mathrm{CO}_{2}+0.8 \mathrm{~N}_{2}+2.8 \mathrm{H}_{2} \mathrm{O} \\
\mathrm{CO}_{2}+\mathrm{H}_{2} \mathrm{O} \leftrightarrow \mathrm{HCO}_{3}^{-}+\mathrm{H}^{+} \\
\mathrm{Ca}^{2+}+\mathrm{HCO}_{3}^{-}+\mathrm{OH}^{-} \rightarrow \mathrm{CaCO}_{3}+2 \mathrm{H}_{2} \mathrm{O}\end{array}$} & Simple production only of carbon dioxide and nitrogen & \multirow{2}{*}{$\begin{array}{l}\text { Diaphorobacter } \\
\text { nitroreducens [15] }\end{array}$} \\
\hline & & Organic calcium ion resource & \\
\hline
\end{tabular}

Table 3 Application methods of bacteria in cementitious composites and characteristic of varying protective materials

\begin{tabular}{|c|c|c|c|c|}
\hline $\begin{array}{l}\text { Application } \\
\text { method }\end{array}$ & Reference & Protective material & Characteristic & Findings \\
\hline \multirow{2}{*}{$\begin{array}{l}\text { Direct } \\
\text { incorporation }\end{array}$} & $\begin{array}{l}\text { Jadhav et al. } \\
{[25]}\end{array}$ & -- & $\begin{array}{l}\text { Geopolymer can act as alternative } \\
\text { environmental-friendly cementitious } \\
\text { composites. }\end{array}$ & $\begin{array}{l}\text { The promising crack healing potential of geopolymer with } \\
\text { direct incorporation of bacteria was observed. }\end{array}$ \\
\hline & $\begin{array}{l}\text { Khaliq et al. } \\
\text { [27] }\end{array}$ & -- & $\begin{array}{l}\text { It ensures low cost and easy manufacture } \\
\text { procedure. }\end{array}$ & $\begin{array}{l}\text { A slight improvement of compressive strength was } \\
\text { observed and crack with width of } 0.37 \mathrm{~mm} \text { was repaired. }\end{array}$ \\
\hline \multirow{4}{*}{ Immobilization } & \multirow{2}{*}{$\begin{array}{l}\text { Khaliq et al. } \\
\text { [27] }\end{array}$} & LWA & $\begin{array}{l}\text { Higher crack healing efficiency in specimens } \\
\text { pre-cracked at later days can be observed. }\end{array}$ & $\begin{array}{l}\text { LWA resulted in a } 12 \% \text { increase in compressive strength } \\
\text { and crack with maximum width of } 0.61 \mathrm{~mm} \text { was repaired. }\end{array}$ \\
\hline & & GNP & $\begin{array}{l}\text { Higher crack healing efficiency in specimens } \\
\text { pre-cracked at early days can be observed. }\end{array}$ & $\begin{array}{l}\text { GNP resulted in a } 9.8 \% \text { increase in compressive strength } \\
\text { and crack with maximum width of } 0.81 \mathrm{~mm} \text { was repaired. }\end{array}$ \\
\hline & \multirow{2}{*}{$\begin{array}{l}\text { Manzur et al. } \\
\text { [34] }\end{array}$} & Brick aggregate & \multirow{2}{*}{$\begin{array}{l}\text { Brick aggregate has abundant sources and } \\
\text { the potential of replacing natural stone } \\
\text { aggregates. }\end{array}$} & $\begin{array}{l}\text { A } 15 \% \text { improvement of compressive strength and a } 37 \% \\
\text { reduction of water permeability were observed. }\end{array}$ \\
\hline & & Brick aggregate with & & An $8 \%$ improvement of compressive strength and a $33 \%$ \\
\hline
\end{tabular}




\begin{tabular}{|c|c|c|c|c|}
\hline & & $\begin{array}{l}\text { bacterial attachment } \\
\text { treatment }\end{array}$ & & reduction of water permeability were observed. \\
\hline & $\begin{array}{l}\text { Bundur et al. } \\
\text { [31] }\end{array}$ & $\begin{array}{l}\text { Pre-wetted lightweight } \\
\text { fine expanded shale } \\
\text { aggregates }\end{array}$ & $\begin{array}{l}\text { This material can act as protective material } \\
\text { and nutrients reservoirs. }\end{array}$ & $\begin{array}{l}\text { An } 8 \% \text { improvement of compressive strength with s/c of } \\
0.3 \text { and a } 2 \% \text { reduction with } \mathrm{s} / \mathrm{c} \text { of } 0.5 \text { were observed. }\end{array}$ \\
\hline & $\begin{array}{l}\text { Xu et al. } \\
{[30]}\end{array}$ & Ceramsite & $\begin{array}{l}\text { Heat treatment and } \mathrm{NaOH} \text { soaking are first } \\
\text { employed to improve the loading content of } \\
\text { the ceramsite. }\end{array}$ & $\begin{array}{l}\text { A over } 20 \% \text { improvement of compressive strength regain } \\
\text { and a } 30 \% \text { reduction of water absorption were observed. }\end{array}$ \\
\hline & $\begin{array}{l}\text { Alazhar et } \\
\text { al. [53] }\end{array}$ & Coated expanded perlite & $\begin{array}{l}\text { Coated expanded perlite is lightweight, } \\
\text { amorphous, mineral aggregate. }\end{array}$ & $\begin{array}{l}\text { Crack healing could be achieved when a suitable ratio of } \\
\text { bacteria cells to calcium acetate was provided. }\end{array}$ \\
\hline & $\begin{array}{l}\text { Seifan et al. } \\
{[36]}\end{array}$ & Iron oxide nanoparticles & $\begin{array}{l}\text { Iron oxide nanoparticles have no adverse } \\
\text { effect on bacterial viability. }\end{array}$ & $\begin{array}{l}\text { A } 74 \%, 43 \% \text { and } 15 \% \text { improvement of compressive } \\
\text { strengths in specimens at } 3 \text { days, } 7 \text { days and } 28 \text { days was } \\
\text { observed respectively. }\end{array}$ \\
\hline & $\begin{array}{l}\text { Xu et al. } \\
{[32]}\end{array}$ & $\begin{array}{l}\text { Calcium sulphoaluminate } \\
\text { cement }\end{array}$ & $\begin{array}{l}\text { Calcium sulphoaluminate cement is low } \\
\text { alkali, fast hardening cementitious } \\
\text { composites. }\end{array}$ & $\begin{array}{l}\text { Bacterial viability was effectively preserved and cracks up } \\
\text { to } 417 \mu \mathrm{m} \text { were healed completely in } 28 \text { days. }\end{array}$ \\
\hline & $\begin{array}{l}\text { Shaheen et } \\
\text { al. [76] }\end{array}$ & Limestone powder & $\begin{array}{l}\text { Limestone powder is an inert media and acts } \\
\text { as a filler. }\end{array}$ & $\begin{array}{l}\text { A } 5 \% \text { improvement of compressive strength was observed } \\
\text { at } 7 \text { days. }\end{array}$ \\
\hline & $\begin{array}{l}\text { Bhaskar et } \\
\text { al. [38] }\end{array}$ & Zeolite & $\begin{array}{l}\text { Zeolite has the property of roughness, large } \\
\text { surface area and high porosity. }\end{array}$ & $\begin{array}{l}\text { Compressive strength increased with bacterial addition for } \\
\text { both normal and fiber cementitious composites, water } \\
\text { absorption and chloride permeability were reduced. }\end{array}$ \\
\hline \multirow{5}{*}{ Encapsulation } & $\begin{array}{l}\text { Palin et al. } \\
\text { [70] }\end{array}$ & $\begin{array}{l}\text { Bead encapsulating } \\
\text { calcium alginate and } \\
\text { bacteria }\end{array}$ & $\begin{array}{l}\text { Bead can swell by } 300 \% \text { reaching their } \\
\text { maximum diameter of } 3 \mathrm{~mm} \text { within } 24 \mathrm{hrs} \text {. }\end{array}$ & $\begin{array}{l}\text { Bacteria encapsulated by bead showed great potential for } \\
\text { realizing self-healing cementitious composites used in the } \\
\text { low-temperature marine environments. }\end{array}$ \\
\hline & \multirow{2}{*}{$\begin{array}{l}\text { Wang et al } \\
{[37]}\end{array}$} & $\begin{array}{l}\text { Glass tube encapsulating } \\
\text { bacteria and silica gel }\end{array}$ & \multirow{2}{*}{$\begin{array}{l}\text { It requires high cost and complex } \\
\text { manufacture procedure }\end{array}$} & $\begin{array}{l}\text { Improvement of less than } 5 \% \text { in compressive strength } \\
\text { regain. } \\
\mathrm{K} \text { value is between } 10^{-9} \text { to } 10^{-7} \cdot \mathrm{s}^{-1} \text {. }\end{array}$ \\
\hline & & $\begin{array}{l}\text { Glass tube encapsulating } \\
\text { bacteria and PU }\end{array}$ & & $\begin{array}{l}\text { Improvement of } 50 \% \text { to } 80 \% \text { in compressive strength } \\
\text { regain } \\
\mathrm{K} \text { value is between } 3 \times 10^{-11} \text { to } 6 \times 10^{-11} \mathrm{~m} \cdot \mathrm{s}^{-1} \text {. }\end{array}$ \\
\hline & $\begin{array}{l}\text { Wang et al } \\
{[4]}\end{array}$ & Hydrogel & $\begin{array}{l}\text { Hydrogel acts as both water reservoirs and } \\
\text { protective material. }\end{array}$ & $\begin{array}{l}\text { Crack with width of } 0.5 \mathrm{~mm} \text { was repaired and a } 68 \% \\
\text { reduction of water permeability was observed. }\end{array}$ \\
\hline & $\begin{array}{l}\text { Wang et al. } \\
\text { [67] }\end{array}$ & $\begin{array}{l}\text { Microcapsule which is } \\
\text { melamine based }\end{array}$ & $\begin{array}{l}\text { Microcapsule contains inert substance to } \\
\text { protect bacteria. }\end{array}$ & $\begin{array}{l}\text { Healing ratio of the specimens with microcapsules was } \\
\text { higher }(48 \%-80 \%) \text { than that of specimens without bacteria } \\
(18 \%-50 \%) \text {. }\end{array}$ \\
\hline
\end{tabular}


Table 4 Summary of researches about bacterial precipitation morphology

\begin{tabular}{|c|c|c|c|}
\hline Reference & Bacteria & Nutrients & Precipitation morphology \\
\hline Williams[20] & Sporosarcina pasteurii & yeast extract and urea & Calcite \\
\hline $\mathrm{Xu}$ et al. [32] & Sporosarcina pasteurii & peptone and beef extract & Calcite \\
\hline $\begin{array}{l}\text { Charpe et } \\
\text { al.[28] }\end{array}$ & Bacteria from soil & urea, gypsum and sugar & Aragonite and calcite. \\
\hline \multirow{2}{*}{$\begin{array}{l}\text { Vashisht et } \\
\text { al.[83] }\end{array}$} & Lysinibacillus sp. & \multirow{2}{*}{--} & \multirow{2}{*}{ Higher calcite precipitation was indicated in Lysinibacillus sp. } \\
\hline & B. megaterium & & \\
\hline \multirow{2}{*}{$\begin{array}{l}\text { Bhaskar et al. } \\
{[38]}\end{array}$} & Sporosarcina ureae & \multirow{2}{*}{ yeast extract, urea, and calcium lactate } & Relatively denser rhombohedral-shaped crystals \\
\hline & Sporosarcina pasteuri & & Relatively scatter rhombohedral-shaped crystals \\
\hline \multirow{2}{*}{ Kim et al.[10] } & S. pasteurii & \multirow{2}{*}{ Urea, calcium acetate and nutrient broth } & Denser and smaller spherical or semi-spherical particle shapes. \\
\hline & B. sphaericus & & Pockmark shapes. calcite and vaterite \\
\hline Joshi et al[50] & Bacillus sp. CT5 & corn steep liquor & Rhombohedral calcite crystal and spheroid vaterite crystals \\
\hline $\begin{array}{l}\text { Choi et al. } \\
{[22]}\end{array}$ & Sp. pasteurii & urea- $\mathrm{CaCl}_{2}$ solution & $\begin{array}{l}\text { Vaterite: the flower-shaped clusters with plate/sheet-like hexagon } \mathrm{CaCO}_{3} \text {. } \\
\text { Calcite: granular clusters of coarse hexagon-shaped } \mathrm{CaCO}_{3} \text { at multiple scales }\end{array}$ \\
\hline \multirow{2}{*}{$\begin{array}{l}\text { Tittelboom et } \\
\text { al. [26] }\end{array}$} & \multirow{2}{*}{ Bacillus sphaericus } & $\mathrm{CaCl}_{2}$ and urea & Calcite, vaterite and aragonite \\
\hline & & $\mathrm{Ca}\left(\mathrm{CH}_{3} \mathrm{COO}\right)_{2}$ and urea & Calcite and vaterite \\
\hline \multirow{3}{*}{$\begin{array}{l}\text { Zhang et al. } \\
\text { [39] }\end{array}$} & \multirow{3}{*}{ Sporosarcina pasteurii } & $\mathrm{CaCl}_{2}$ & Hexahedral crystals \\
\hline & & $\mathrm{Ca}\left(\mathrm{NO}_{3}\right)_{2}$ & Hexahedral crystals with rough surface \\
\hline & & $\mathrm{Ca}(\mathrm{CH} 3 \mathrm{COO})_{2}$ & Acicular crystals, small amount of spherical and lettuce-like crystals \\
\hline \multirow{3}{*}{$\begin{array}{l}\text { Amiri } \\
\text { al.[40] }\end{array}$} & \multirow{3}{*}{ Sporosarcina pasteurii } & $\begin{array}{l}\mathrm{CaCl}_{2} \text { and } \mathrm{UCSL} \text { (Tris base, urea and corn } \\
\text { steep liquor) }\end{array}$ & Rhombohedral calcite and spheroid vaterite \\
\hline & & $\begin{array}{l}\mathrm{Ca}\left(\mathrm{NO}_{3}\right) \text { and UCSL(Tris base, urea and } \\
\text { corn steep liquor) }\end{array}$ & Spheroid vaterite \\
\hline & & $\mathrm{CaCl}_{2}$ and urea-yeast extract (UYE) & Rhombohedral calcite and spheroid vaterite \\
\hline
\end{tabular}


Table 5 The effect of different kinds of bacteria, bacteria concentration and nutrients on mechanical properties

\begin{tabular}{|c|c|c|c|c|c|c|}
\hline $\begin{array}{l}\text { Influencing } \\
\text { factor }\end{array}$ & Reference & Bacteria & $\begin{array}{l}\text { Bacterial } \\
\text { concentration }\end{array}$ & Nutrients & Increase of compressive strength & $\begin{array}{l}\text { Increase of split } \\
\text { tensile strength }\end{array}$ \\
\hline \multirow{19}{*}{ Bacterial type } & \multirow{3}{*}{$\begin{array}{l}\text { Bashir et al. } \\
\text { [56] }\end{array}$} & Bacillus Subtilis & \multirow{3}{*}{--} & \multirow{3}{*}{--} & $9.16 \%$ & $14.41 \%$ \\
\hline & & Bacillus Sphaericus & & & $52.42 \%$ & $2.76 \%$ \\
\hline & & Bacillus Pasteurii & & & $29.97 \%$ & -- \\
\hline & \multirow{2}{*}{$\begin{array}{l}\text { Jagannathan } \\
\text { et al.[47] }\end{array}$} & Bacillus Sphaericus & \multirow{2}{*}{--} & \multirow{2}{*}{--} & $10.8 \%$ & $29.3 \%$ \\
\hline & & Bacillus Pasteurii & & & $-9.8 \%$ & $-13.4 \%$ \\
\hline & \multirow{2}{*}{$\begin{array}{l}\text { Vashisht et } \\
\text { al. [83] }\end{array}$} & Bacillus. megaterium & \multirow{2}{*}{--} & \multirow{2}{*}{--} & $14.8 \%$ & -- \\
\hline & & Lysinibacillus sp. I13 & & & $34.6 \%$ & -- \\
\hline & \multirow{2}{*}{$\begin{array}{l}\text { Ghosh et } \\
\text { al.[24] }\end{array}$} & Shewanella & \multirow{2}{*}{$10^{5} \mathrm{cell} / \mathrm{ml}$} & \multirow{2}{*}{--} & $25 \%$ & -- \\
\hline & & Escherichia coli & & & No improvement & -- \\
\hline & \multirow{2}{*}{$\begin{array}{l}\text { Bhaskar et } \\
\text { al. [42] }\end{array}$} & Sporosarcina pasteurii & \multirow{2}{*}{$10^{6}$ cells $/ \mathrm{ml}$} & \multirow{2}{*}{$\begin{array}{l}0.2 \% \text { yeast extract, } 2 \% \\
\text { urea, and } 2 \% \text { calcium } \\
\text { lactate of cement mass }\end{array}$} & \multirow{2}{*}{$\begin{array}{l}\text { Specimen with Sporosarcina ureae } \\
\text { was } 8 \% \text { lower than that of } \\
\text { Sporosarcina pasteuri }\end{array}$} & -- \\
\hline & & Sporosarcina ureae & & & & -- \\
\hline & \multirow{8}{*}{$\begin{array}{l}\text { Irwan et al. } \\
{[59]}\end{array}$} & \multirow{4}{*}{ Enterococcus faecalis } & \multirow{4}{*}{$\begin{array}{l}3 \% \text { replacement } \\
\text { of water }\end{array}$} & No calcium lactate & $6.11 \%$ & -- \\
\hline & & & & $0.001 \mathrm{~mol} / \mathrm{l}$ calcium lactate & $6.9 \%$ & -- \\
\hline & & & & $0.005 \mathrm{~mol} / \mathrm{l}$ calcium lactate & $18.9 \%$ & -- \\
\hline & & & & $0.01 \mathrm{~mol} / \mathrm{l}$ calcium lactate & $8.3 \%$ & -- \\
\hline & & \multirow{4}{*}{ Bacillus sp. } & \multirow{4}{*}{$\begin{array}{l}5 \% \text { replacement } \\
\text { of water }\end{array}$} & No calcium lactate & $2.7 \%$ & -- \\
\hline & & & & $0.001 \mathrm{~mol} / \mathrm{l}$ calcium lactate & $6.9 \%$ & -- \\
\hline & & & & $0.005 \mathrm{~mol} / \mathrm{l}$ calcium lactate & $10 \%$ & -- \\
\hline & & & & $0.01 \mathrm{~mol} / \mathrm{l}$ calcium lactate & $5 \%$ & -- \\
\hline \multirow{10}{*}{$\begin{array}{l}\text { Bacterial } \\
\text { concentration }\end{array}$} & \multirow{3}{*}{$\begin{array}{l}\text { Jagannathan } \\
\text { et al. [47] }\end{array}$} & \multirow{3}{*}{ Bacillus sphaericus } & $10^{3}$ cells $\cdot \mathrm{ml}^{-1}$ & \multirow{3}{*}{ nutrient broth and urea } & $9.4 \%$ & $9.56 \%$ \\
\hline & & & $10^{5}$ cells $\cdot \mathrm{ml}^{-1}$ & & $15.83 \%$ & $18.59 \%$ \\
\hline & & & $10^{7}$ cells $\cdot \mathrm{ml}^{-1}$ & & $12.3 \%$ & $16.66 \%$ \\
\hline & \multirow{3}{*}{$\begin{array}{l}\text { Mondal et al. } \\
{[41]}\end{array}$} & \multirow{3}{*}{ Bacillus subtilis } & $10^{3}$ cells $\cdot \mathrm{ml}^{-1}$ & \multirow{3}{*}{--} & $15 \%$ & -- \\
\hline & & & $10^{5}$ cells $\cdot \mathrm{ml}^{-1}$ & & $27 \%$ & -- \\
\hline & & & $10^{7}$ cells $\cdot \mathrm{ml}^{-1}$ & & $19 \%$ & -- \\
\hline & \multirow{4}{*}{$\begin{array}{l}\text { Ghosh et al. } \\
{[66]}\end{array}$} & \multirow{4}{*}{ Shewanella } & $10^{4}$ cells $\cdot \mathrm{ml}^{-1}$ & & $9.98 \%$ & -- \\
\hline & & & $10^{5}$ cells $\cdot \mathrm{ml}^{-1}$ & & $25.29 \%$ & -- \\
\hline & & & $10^{6}$ cells $\cdot \mathrm{ml}^{-1}$ & -- & $14.65 \%$ & -- \\
\hline & & & $10^{7}$ cells $\cdot \mathrm{ml}^{-1}$ & & $11.06 \%$ & -- \\
\hline
\end{tabular}




\begin{tabular}{|c|c|c|c|c|c|c|}
\hline & \multirow{4}{*}{$\begin{array}{l}\text { Rao et al. } \\
{[43]}\end{array}$} & \multirow{4}{*}{ Bacillus subtilis JC3 } & $10^{4}$ cells $\cdot \mathrm{ml}^{-1}$ & \multirow{4}{*}{--} & $11.68 \%$ & -- \\
\hline & & & $10^{5}$ cells $\cdot \mathrm{ml}^{-1}$ & & $20.63 \%$ & $25 \%$ \\
\hline & & & $10^{6}$ cells $\cdot \mathrm{ml}^{-1}$ & & $15.46 \%$ & -- \\
\hline & & & $10^{7}$ cells $\cdot \mathrm{ml}^{-1}$ & & $7.48 \%$ & -- \\
\hline & \multirow{3}{*}{$\begin{array}{l}\text { Chahal et al. } \\
\text { [48] }\end{array}$} & \multirow{3}{*}{$\begin{array}{l}\text { Sporoscarcina pasteurii } \\
\text { (cement was replaced } \\
\text { by } 10 \% \text { fly ash) }\end{array}$} & $10^{3}$ cells $\cdot \mathrm{ml}^{-1}$ & \multirow{3}{*}{--} & $4.1 \%$ & -- \\
\hline & & & $10^{5}$ cells $\cdot \mathrm{ml}^{-1}$ & & $20 \%$ & -- \\
\hline & & & $10^{7}$ cells $\cdot \mathrm{ml}^{-1}$ & & $8.7 \%$ & -- \\
\hline & \multirow{3}{*}{$\begin{array}{l}\text { Chahal et al. } \\
\text { [61] }\end{array}$} & \multirow{3}{*}{$\begin{array}{l}\text { Sporoscarcina } \\
\text { pasteurii) }\end{array}$} & $10^{3}$ cells $\cdot \mathrm{ml}^{-1}$ & \multirow{3}{*}{--} & \multirow{3}{*}{$\begin{array}{l}\text { Maximum increase was observed in } \\
\text { specimen with } 10^{5} \text { cells } \cdot \mathrm{ml}^{-1}\end{array}$} & -- \\
\hline & & & $10^{5}$ cells $\cdot \mathrm{ml}^{-1}$ & & & -- \\
\hline & & & $10^{7}$ cells $\cdot \mathrm{ml}^{-1}$ & & & -- \\
\hline & \multirow{3}{*}{$\begin{array}{l}\text { Andalib et al. } \\
{[42]}\end{array}$} & \multirow{3}{*}{ Bacillus megaterium } & $20 \times 10^{5} \mathrm{cfu} \cdot \mathrm{ml}^{-1}$ & \multirow[t]{3}{*}{--} & \multirow{3}{*}{$30 \times 10^{5} \mathrm{cfu} \cdot \mathrm{ml}^{-1} \mathrm{was}$ found to be ideal. } & \multirow{3}{*}{--} \\
\hline & & & $30 \times 10^{5} \mathrm{cfu} \cdot \mathrm{ml}^{-1}$ & & & \\
\hline & & & $40 \times 10^{5} \mathrm{cfu} \cdot \mathrm{ml}^{-1}$ & & & \\
\hline \multirow{14}{*}{ Nutrients } & \multirow{3}{*}{$\begin{array}{l}\text { Irwan et al. } \\
{[51]}\end{array}$} & \multirow{3}{*}{ Enterococcus faecalis } & \multirow{3}{*}{$\begin{array}{l}3 \% \text { replacement } \\
\text { of water }\end{array}$} & $0.001 \mathrm{~mol} \cdot \mathrm{L}^{-1} \mathrm{CaCl}_{2}$ & $18.9 \%$ & $0.7 \%$ \\
\hline & & & & $0.005 \mathrm{~mol} \cdot \mathrm{L}^{-1} \mathrm{CaCl}_{2}$ & $6.9 \%$ & $18.5 \%$ \\
\hline & & & & $0.01 \mathrm{~mol} \cdot \mathrm{L}^{-1} \mathrm{CaCl}_{2}$ & $8.3 \%$ & $1.5 \%$ \\
\hline & \multirow{3}{*}{$\begin{array}{l}\text { Zhang et al. } \\
\text { [39] }\end{array}$} & \multirow{3}{*}{ Sporosarcina Pasteurii } & \multirow{3}{*}{--} & $\begin{array}{lll}\mathrm{Ca}\left(\mathrm{NO}_{3}\right)_{2} & \text { solution } & \text { and } \\
0.5 \mathrm{M} \text { urea } & & \\
\end{array}$ & \multirow{3}{*}{$\begin{array}{l}\text { Uniaxial compressive strength of } \\
\text { specimen with } \mathrm{Ca}\left(\mathrm{CH}_{3} \mathrm{COO}\right)_{2} \text { were } \\
\text { about twice that with } \mathrm{CaCl}_{2} \text { and } \\
\mathrm{Ca}\left(\mathrm{NO}_{3}\right)_{2}\end{array}$} & $13.0 \%$ \\
\hline & & & & $\begin{array}{l}\mathrm{Ca}\left(\mathrm{CH}_{3} \mathrm{COO}\right)_{2} \text { solution and } \\
0.5 \mathrm{M} \text { urea }\end{array}$ & & $18.0 \%$ \\
\hline & & & & $\begin{array}{l}\mathrm{CaCl}_{2} \text { solution and } 0.5 \mathrm{M} \\
\text { urea }\end{array}$ & & $18.6 \%$ \\
\hline & \multirow{2}{*}{$\begin{array}{l}\text { Tziviloglou } \\
\text { et al. [84] }\end{array}$} & \multirow{2}{*}{ Species of Bacillus } & \multirow{2}{*}{--} & $\begin{array}{l}\text { Calcium lactate solution } \\
\text { and yeast extract }\end{array}$ & $8 \%$ & -- \\
\hline & & & & $\begin{array}{l}\text { Calcium acetate solution } \\
(\mathrm{CaA}) \text { and yeast extract }\end{array}$ & $13.4 \%$ & -- \\
\hline & \multirow{2}{*}{$\begin{array}{l}\text { Amiri et al. } \\
\text { [59] }\end{array}$} & \multirow{2}{*}{ Sporosarcina pasteurii } & \multirow{2}{*}{$8 \times 10^{8} \mathrm{cfu} \cdot \mathrm{ml}^{-1}$} & urea-yeast extrac & \multirow{2}{*}{$\begin{array}{l}\text { CSL did not have adverse effect } \\
\text { compressive strength }\end{array}$} & -- \\
\hline & & & & urea-corn steep liquor & & -- \\
\hline & \multirow{3}{*}{$\begin{array}{l}\text { Thiyagarajan } \\
\text { et al. [52] }\end{array}$} & \multirow{3}{*}{ Bacillus sphaericus } & & water & & -- \\
\hline & & & $\begin{array}{l}10^{0} \text { cells } \cdot \mathrm{ml}^{-1}, \\
10^{8} \mathrm{cell} \cdot \mathrm{l} \cdot \mathrm{ml}^{-1}\end{array}$ & luria bertania broth & Increase of specimen with wastewater & -- \\
\hline & & & & wastewater & & -- \\
\hline & $\begin{array}{l}\text { Joshi et al. } \\
{[50]}\end{array}$ & Bacillus sp. CT5 & -- & $\begin{array}{l}\text { Corn steep liquor and urea- } \\
\mathrm{CaCl}_{2}\end{array}$ & -- & $25 \%$ \\
\hline
\end{tabular}




\begin{tabular}{l|l|l|l|l|l|l}
\hline & & & & $\begin{array}{l}\text { nutrient broth and urea- } \\
\mathrm{CaCl}_{2}\end{array}$ & $29 \%$ \\
\hline
\end{tabular}


Table 6 Summary of researches on durability

\begin{tabular}{|c|c|c|c|}
\hline Aspect & Researches objectives & Findings & Reference \\
\hline \multirow[b]{2}{*}{ Porosity } & $\begin{array}{l}\text { Investigate the influence of } \\
\text { addition of bacteria on porosity. }\end{array}$ & $\begin{array}{l}\text { Addition of bacteria reduced porosity } \\
\text { by } 50 \% \text {. }\end{array}$ & $\begin{array}{l}\text { Achal et } \\
\text { al. [57] }\end{array}$ \\
\hline & $\begin{array}{l}\text { Investigate the influence of } \\
\text { addition of bacteria on porosity. }\end{array}$ & $\begin{array}{l}\text { Addition of bacterial reduced porosity } \\
\text { by nearly } 70 \% \text { from Ultrasonic Pulse } \\
\text { Velocity test. }\end{array}$ & $\begin{array}{l}\text { Rao et al. } \\
{[43]}\end{array}$ \\
\hline \multirow{9}{*}{$\begin{array}{l}\text { Water } \\
\text { absorption }\end{array}$} & $\begin{array}{l}\text { Investigate the influence of } \\
\text { addition of bacteria on water } \\
\text { absorption. }\end{array}$ & $\begin{array}{l}\text { Addition of bacterial reduced water } \\
\text { absorption by nearly } 50 \%-80 \% \text {. }\end{array}$ & $\begin{array}{l}\text { Rao et al. } \\
{[43]}\end{array}$ \\
\hline & $\begin{array}{l}\text { Investigate the influence of } \\
\text { addition of local soil bacteria } \\
\text { on water absorption. }\end{array}$ & $\begin{array}{l}\text { Addition of local soil bacteria } \\
\text { reduced water absorption by } 7.79 \% \text {, } \\
9.44 \% \text { and } 15.40 \% \text { for } 3,7 \text { and } 28 \\
\text { days respectively. }\end{array}$ & $\begin{array}{l}\text { Charpe et } \\
\text { al. [28] }\end{array}$ \\
\hline & $\begin{array}{l}\text { Investigate the influence of } \\
\text { bacteria and different } \\
\text { percentage of volcanic ash in } \\
\text { specimen on water absorption. }\end{array}$ & $\begin{array}{l}\text { Bacterial technology-enabled } \\
\text { cementitious composites with } 1.5 \% \\
\text { volcanic ash had average water } \\
\text { absorption reduction of } 23 \%\end{array}$ & $\begin{array}{l}\text { Purwanto } \\
\text { et al. [85] }\end{array}$ \\
\hline & $\begin{array}{l}\text { Investigate the influence of } \\
\text { bacteria and different } \\
\text { percentage of fly ash in } \\
\text { specimen on water absorption. }\end{array}$ & $\begin{array}{l}\text { Bacterial technology-enabled } \\
\text { cementitious composites with } 30 \% \text { of } \\
\text { fly ash had a reduction of } 30 \% \text { in } \\
\text { water absorption. }\end{array}$ & $\begin{array}{l}\text { Kadapure } \\
\text { et al. [13] }\end{array}$ \\
\hline & $\begin{array}{l}\text { Investigate the influence of } \\
\text { different bacteria on water } \\
\text { absorption. }\end{array}$ & $\begin{array}{l}\text { Pure cultures resulted in a more } \\
\text { pronounced decrease water } \\
\text { absorption than the mixed cultures. }\end{array}$ & $\begin{array}{l}\text { Muynck } \\
\text { et al. [54] }\end{array}$ \\
\hline & $\begin{array}{l}\text { Investigate the influence of } \\
\text { different bacteria concentration } \\
\text { and different percentage of } \\
\text { silica fume in specimen on } \\
\text { water absorption. }\end{array}$ & $\begin{array}{l}\text { Maximum reduction in water } \\
\text { absorption with } 105 \text { cells } \cdot \text { ml- } 1 \text { for } \\
10 \% \text { silica fume concrete as water } \\
\text { absorption was observed at } 91 \text { days. }\end{array}$ & $\begin{array}{l}\text { Chahal et } \\
\text { al. [61] }\end{array}$ \\
\hline & $\begin{array}{l}\text { Investigate the influence of } \\
\text { different bacteria concentration } \\
\text { and different percentage of fly } \\
\text { ash in specimen on water } \\
\text { absorption. }\end{array}$ & $\begin{array}{l}\text { Optimum reduction in water } \\
\text { absorption was observed in specimen } \\
\text { contained fly ash with concentration } \\
\text { of } 105 \text { cells } \cdot \mathrm{ml}-1 \text { and } 107 \text { cells } \cdot \mathrm{ml}-1 \text {. }\end{array}$ & $\begin{array}{l}\text { Chahal et } \\
\text { al. [48] }\end{array}$ \\
\hline & $\begin{array}{l}\text { Investigate the influence of } \\
\text { bacteria concentration on water } \\
\text { absorption. }\end{array}$ & $\begin{array}{l}\text { Water absorption was reduced by } \\
13 \%, 23 \% \text { and } 27 \% \text { for } \\
\text { concentrations of } 103 \text { cells } \cdot \mathrm{ml}-1,105 \\
\text { cells } \cdot \mathrm{ml}-1 \text { and } 107 \text { cells } \cdot \mathrm{ml}-1 \text {. }\end{array}$ & $\begin{array}{l}\text { Mondal } \\
\text { et al.[41]. }\end{array}$ \\
\hline & $\begin{array}{l}\text { Investigate the influence of } \\
\text { different nutrients on water } \\
\text { absorption. }\end{array}$ & $\begin{array}{l}\text { Specimens with nutrients of corn } \\
\text { steep liquor presented significantly } \\
\text { lower water absorption than that of } \\
\text { nutrient broth with uera-CaCl2. }\end{array}$ & $\begin{array}{l}\text { Joshi et } \\
\text { al.[50] }\end{array}$ \\
\hline \multirow{3}{*}{$\begin{array}{l}\text { Water } \\
\text { permeability }\end{array}$} & $\begin{array}{l}\text { Investigate the influence of } \\
\text { addition of bacteria on water } \\
\text { permeability. }\end{array}$ & $\begin{array}{l}\text { Addition of bacteria reduced water } \\
\text { permeability by } 70-90 \% \text {. }\end{array}$ & $\begin{array}{l}\text { Rao et al. } \\
{[43]}\end{array}$ \\
\hline & $\begin{array}{l}\text { Investigate the influence of } \\
\text { different nutrients on water } \\
\text { permeability. }\end{array}$ & $\begin{array}{l}\text { Specimen with nutrients of corn steep } \\
\text { liquor had the water penetration depth } \\
\text { of } 28.2 \mathrm{~mm} \text {, while that of nutrient } \\
\text { broth was } 31.2 \mathrm{~mm} \text {. }\end{array}$ & $\begin{array}{l}\text { Joshi et } \\
\text { al. }[50]\end{array}$ \\
\hline & $\begin{array}{l}\text { Investigate the influence of } \\
\text { bacteria type and bacteria } \\
\text { concentration on water } \\
\text { permeability. }\end{array}$ & $\begin{array}{l}\text { Optimum water permeability was } \\
\text { observed in specimen with } \\
\text { concentration of calcium lactate with } \\
0.01 \mathrm{~mol} \cdot 1-1 \text { for Enterococcus faecalis } \\
\text { and Bacillus sp., which are } 8.7 \mathrm{~cm} \\
\text { and } 8 \mathrm{~cm} \text { respectively }\end{array}$ & $\begin{array}{l}\text { Irwan et } \\
\text { al. [59] }\end{array}$ \\
\hline Chloride & Investigate the influence of & Addition of bacteria reduced chloride & Rao et al. \\
\hline
\end{tabular}




\begin{tabular}{|c|c|c|c|}
\hline \multirow[t]{4}{*}{ permeability } & $\begin{array}{l}\text { addition of bacteria on chloride } \\
\text { permeability. }\end{array}$ & $\begin{array}{l}\text { permeability by between } 85 \% \text { and } \\
90 \% \text {. }\end{array}$ & [43] \\
\hline & $\begin{array}{l}\text { Investigate the influence of } \\
\text { addition of bacteria on chloride } \\
\text { permeability by testing } \\
\text { corrosion products of } \\
\text { reinforcement. }\end{array}$ & $\begin{array}{l}\text { Less corrosion products and lower } \\
\text { weight-loss ratio of reinforcements } \\
\text { were observed in bacterial } \\
\text { technology-enabled cementitious } \\
\text { composites which slowed down the } \\
\text { process of reinforcement's corrosion. }\end{array}$ & $\begin{array}{l}\text { Ling et } \\
\text { al. [60] }\end{array}$ \\
\hline & $\begin{array}{l}\text { Investigate the better } \\
\text { performance of on chloride } \\
\text { permeability between specimen } \\
\text { under surface treatment and } \\
\text { specimen admixed with } \\
\text { bacteria. }\end{array}$ & $\begin{array}{l}\text { Specimen under surface treatment } \\
\text { and specimen admixed with bacteria } \\
\text { had the total charge passed of } 1310 \\
\text { coulombs and } 1228 \text { coulombs } \\
\text { respectively. }\end{array}$ & $\begin{array}{l}\text { Joshi et } \\
\text { al. }[50]\end{array}$ \\
\hline & $\begin{array}{l}\text { Investigate the influence of } \\
\text { bacteria concentration on } \\
\text { chloride permeability. }\end{array}$ & $\begin{array}{l}\text { Maximum reduction in chloride ions } \\
\text { was observed with optimum bacterial } \\
\text { concentration of } 105 \text { cells } \cdot \mathrm{ml}-1 \text { for } \\
\text { specimen with different percentage of } \\
\text { fly ash. }\end{array}$ & $\begin{array}{l}\text { Chahal et } \\
\text { al. [48] }\end{array}$ \\
\hline
\end{tabular}

Table 7 Effects of microbiological deposited $\mathrm{CaCO}_{3}$ layer induced by different treatment methods [21]

\begin{tabular}{l|l|l|l|l}
\hline \multirow{2}{*}{ Treatment } & $\begin{array}{l}\mathrm{CaCO} \text { particle } \\
\text { diameter }(\mu \mathrm{m}) \\
\end{array}$ & morphology) & $\begin{array}{l}\text { Thickness of } \\
\mathrm{CaCO}_{3} \text { film }\end{array}$ & \multicolumn{2}{|c|}{\begin{tabular}{l} 
Coefficient of capillary suction \\
\cline { 3 - 5 }
\end{tabular}} & $\begin{array}{l}\text { Absolute value } \\
\left(\mathrm{g} \cdot \mathrm{m}^{-2} \cdot \mathrm{h}^{-0.5}\right)\end{array}$ & $\begin{array}{c}\text { Decreased } \\
\text { degree }(\%)\end{array}$ \\
\hline Immersing & 100 (sphere with arris) & $280-330$ & 290.2 & 83 \\
\hline Spraying & 10 (spherical) & $70-100$ & 399.6 & 76 \\
\hline $\begin{array}{l}\text { Brushing with } \\
\text { sodium alginate }\end{array}$ & 5 (spherical) & $100-120$ & 191.4 & 89 \\
\hline Brushing with agar & 10 (amorphous) & $100-120$ & 174.6 & 90 \\
\hline
\end{tabular}

Table 8 Some researches about self-healing ability

\begin{tabular}{|c|c|c|c|}
\hline Objectives & Reference & Crack healing assessment & Conclusion \\
\hline \multirow{2}{*}{$\begin{array}{l}\text { Investigate the } \\
\text { influence of } \\
\text { crack width on } \\
\text { self-healing } \\
\text { ability }\end{array}$} & Luo et al. [68] & $\begin{array}{l}\text { Self-healing was limited for specimens } \\
\text { with crack width up to } 0.8 \mathrm{~mm} \text {. }\end{array}$ & \multirow{2}{*}{$\begin{array}{l}\text { The self-healing } \\
\text { ability decreases } \\
\text { with the increase } \\
\text { of crack width. }\end{array}$} \\
\hline & $\begin{array}{l}\text { Qian et al. } \\
{[63]}\end{array}$ & $\begin{array}{l}\text { Self-healing ratio of cracks below } 0.4 \mathrm{~mm} \\
\text { reached over } 90 \% \text { while that above } 0.9 \mathrm{~mm} \\
\text { is below } 30 \% \text {. }\end{array}$ & \\
\hline \multirow{3}{*}{$\begin{array}{l}\text { Investigate the } \\
\text { influence of } \\
\text { crack age on } \\
\text { self-healing } \\
\text { ability }\end{array}$} & Luo et al. [68] & $\begin{array}{l}\text { The self-healing ratio was very small when } \\
\text { the cracking age was more than } 60 \text { days. }\end{array}$ & \multirow{3}{*}{$\begin{array}{l}\text { The self-healing } \\
\text { ability decreases } \\
\text { with the increase } \\
\text { of cracking age. }\end{array}$} \\
\hline & $\begin{array}{l}\text { Bhaskar et al. } \\
{[38]}\end{array}$ & $\begin{array}{l}\text { Pronounced self-healing occurred during } \\
\text { the initial four months while less self- } \\
\text { healing occurred in the later stages. }\end{array}$ & \\
\hline & $\begin{array}{l}\text { Qian et al. } \\
{[63]}\end{array}$ & $\begin{array}{l}\text { The self-healing efficiency decreased from } \\
7 \text { days to } 60 \text { days. }\end{array}$ & \\
\hline \multirow{3}{*}{$\begin{array}{l}\text { Investigate the } \\
\text { influence of } \\
\text { curing ways on } \\
\text { self-healing } \\
\text { ability }\end{array}$} & Luo et al. [68] & $\begin{array}{l}\text { The self-healing efficiency of specimen } \\
\text { with water curing was better than that with } \\
\text { wet-dry cycles curing. }\end{array}$ & \multirow{3}{*}{$\begin{array}{l}\text { The curing type } \\
\text { makes a } \\
\text { difference on } \\
\text { crack healing } \\
\text { ability and } \\
\text { liquid water is } \\
\text { essential to } \\
\text { realize self- } \\
\text { healing. }\end{array}$} \\
\hline & $\begin{array}{l}\text { Suleiman et } \\
\text { al. [69] }\end{array}$ & $\begin{array}{l}\text { No significant self-healing occurred in } \\
\text { specimens exposed to both cyclic } \\
\text { temperature and cyclic relative humidity. }\end{array}$ & \\
\hline & $\begin{array}{l}\text { Wang et al. } \\
{[67]}\end{array}$ & $\begin{array}{l}\text { No self-healing was observed in specimens } \\
\text { with encapsulated bacteria cured at } 95 \% \\
\text { RH. Wet-dry cycle treatment was the best } \\
\text { incubation condition for specimens with } \\
\text { bacteria. }\end{array}$ & \\
\hline
\end{tabular}


Table 9 Recent researches which has the potential about reducing the costs

\begin{tabular}{|c|c|c|c|}
\hline $\begin{array}{l}\text { Factor to } \\
\text { reduce cost }\end{array}$ & Reference & Research objective & Findings \\
\hline \multirow{4}{*}{$\begin{array}{l}\text { Bacteria } \\
\text { and } \\
\text { manufacture }\end{array}$} & Pei et. al [19] & $\begin{array}{l}\text { Observe the influence of live } \\
\text { bacteria, dead bacteria and } \\
\text { bacterial cell wall on property } \\
\text { of specimen respectively. }\end{array}$ & $\begin{array}{l}\text { Bacterial cell walls of Bacillus } \\
\text { subtilis significantly increased } \\
\text { compressive strength and } \\
\text { decreased porosity while its dead } \\
\text { cell did not any contributes. }\end{array}$ \\
\hline & $\begin{array}{l}\text { Williams et } \\
\text { al.[20] }\end{array}$ & $\begin{array}{l}\text { Investigate the ability to } \\
\text { precipitate calcium carbonate } \\
\text { of dead bacteria. }\end{array}$ & $\begin{array}{l}\text { Bacterial precipitation would } \\
\text { proceed because bacteria cells } \\
\text { could act as nucleation sites in } \\
\text { cementitious composites. }\end{array}$ \\
\hline & $\begin{array}{l}\text { Jadhav et al. } \\
\text { [29] }\end{array}$ & $\begin{array}{l}\text { Investigate crack healing } \\
\text { ability of specimen using } \\
\text { geopolymer with direct } \\
\text { incorporation of bacteria. }\end{array}$ & $\begin{array}{l}\text { The crack was filled and bacteria } \\
\text { remained viable even at later age, } \\
\text { and cost of bacteria and } \\
\text { manufacture was reduced. }\end{array}$ \\
\hline & $\begin{array}{l}\text { Sharma et } \\
\text { al.[86] }\end{array}$ & $\begin{array}{l}\text { Investigate the potential of B. } \\
\text { pseudofirmus used in crack } \\
\text { healing. }\end{array}$ & $\begin{array}{l}\text { B. pseudofirmus showed potential } \\
\text { for remediation on a commercial } \\
\text { scale due to its quick growth. }\end{array}$ \\
\hline \multirow{5}{*}{ Nutrients } & $\begin{array}{l}\text { Joshi et al. } \\
{[50]}\end{array}$ & $\begin{array}{l}\text { Apply corn steep liquor } \\
\text { (CSL), an industrial by- } \\
\text { product, as nutrients. }\end{array}$ & $\begin{array}{l}\text { Bacterial precipitation occurred } \\
\text { and compressive strength } \\
\text { increased, CSL could act as an } \\
\text { alternate nutrient. }\end{array}$ \\
\hline & $\begin{array}{l}\text { Charpe et al } \\
{[28]}\end{array}$ & $\begin{array}{l}\text { Use lentil seed powder as } \\
\text { protein source and sugar as a } \\
\text { carbon source. }\end{array}$ & $\begin{array}{l}\text { Bacterial precipitation occurred, } \\
\text { enhancement of compressive } \\
\text { strength and reduction of water } \\
\text { absorption were observed. }\end{array}$ \\
\hline & $\begin{array}{l}\text { Palin et } \\
\text { al.[71] }\end{array}$ & $\begin{array}{l}\text { Investigate the economic } \\
\text { nutrients used in marine } \\
\text { environment. }\end{array}$ & $\begin{array}{l}\text { Magnesium acetate, saccharin } \\
\text { sodium, gum Arabic and } \\
\text { magnesium lactate seemed } \\
\text { promising. }\end{array}$ \\
\hline & $\begin{array}{l}\text { Alshalif et al. } \\
\text { [87] }\end{array}$ & $\begin{array}{l}\text { Use bacteria isolated from } \\
\text { cement kiln dust with high } \mathrm{pH} \\
(\mathrm{pH}>11) \text { without nutrients. }\end{array}$ & $\begin{array}{l}\text { The bacteria could grow in high- } \\
\text { pH environment. Cement kiln dust } \\
\text { represented the most appropriate } \\
\text { nutrients source. }\end{array}$ \\
\hline & $\begin{array}{l}\text { Ghosh et al. } \\
{[88]}\end{array}$ & $\begin{array}{l}\text { Investigate bacterial } \\
\text { precipitation efficiency of } \\
\text { anaerobe bacteria, } \\
\text { Escherichia coli strain DH- } 5 \alpha \\
\text { in cementitious composites, }\end{array}$ & $\begin{array}{l}\text { Escherichia coli strain DH- } 5 \alpha \text { grow } \\
\text { well inside the cementitious } \\
\text { composites without supply of } \\
\text { oxygen or nutrients }\end{array}$ \\
\hline \multirow{2}{*}{$\begin{array}{l}\text { Protective } \\
\text { material }\end{array}$} & Xu et al. [32] & $\begin{array}{l}\text { Use calcium sulphoaluminate } \\
\text { cement, a low alkali, fast } \\
\text { hardening material, as } \\
\text { protective material. }\end{array}$ & $\begin{array}{l}\text { Cracks were filled and bacterial } \\
\text { precipitation was partially } \\
\text { observed in the surface of the } \\
\text { specimens. }\end{array}$ \\
\hline & $\begin{array}{l}\text { Shaheen et al. } \\
{[76]}\end{array}$ & $\begin{array}{l}\text { Use limestone powder as } \\
\text { protective material. }\end{array}$ & $\begin{array}{l}\text { The addition of B. subtilis } \\
\text { immobilized by limestone powder } \\
\text { improved the compressive } \\
\text { strength. }\end{array}$ \\
\hline
\end{tabular}

Table 10 Benefit/cost Ratio for bacterial technology-enabled cementitious composites with reference to corresponding silica fume cementitious composites [78]

\begin{tabular}{|c|c|c|c|c|c|c|c|c|c|c|}
\hline \multirow{2}{*}{ Property } & \multirow{2}{*}{$\begin{array}{l}\text { Weightage } \\
\text { Factor }\end{array}$} & \multicolumn{3}{|l|}{ BSF0 } & \multicolumn{3}{|c|}{ BSF5 } & \multicolumn{3}{|c|}{ BSF10 } \\
\hline & & A & B & $\mathrm{C}$ & A & $\mathrm{B}$ & $\mathrm{C}$ & A & B & $\mathrm{C}$ \\
\hline $\begin{array}{l}\text { Compressive } \\
\text { Strength (MPa) }\end{array}$ & 10 & 36.6 & 0.11 & 1.12 & 38.4 & 0.10 & 1.34 & 43.1 & 0.11 & 1.14 \\
\hline $\begin{array}{l}\text { Permeability } \\
\text { (Coulumbs) }\end{array}$ & 10 & 1993 & 0.21 & 2.10 & 1338 & 0.13 & 1.30 & 912 & 0.05 & 0.51 \\
\hline
\end{tabular}




\begin{tabular}{|c|c|c|c|c|c|c|c|c|c|c|}
\hline $\begin{array}{l}\text { Water Porosity } \\
(\%)\end{array}$ & 10 & 3.07 & 0.55 & 5.50 & 2.67 & 0.53 & 5.30 & 2.36 & 0.52 & 5.20 \\
\hline $\begin{array}{l}\text { Water Absorption } \\
(\%)\end{array}$ & 10 & 1.22 & 0.47 & 4.70 & 1.07 & 0.42 & 4.20 & 0.85 & 0.48 & 4.80 \\
\hline Benefit & & \multicolumn{3}{|l|}{13.42} & \multicolumn{3}{|c|}{12.14} & \multicolumn{3}{|c|}{11.65} \\
\hline Primary Cost (Rs.) & & \multicolumn{3}{|l|}{3800} & \multicolumn{3}{|c|}{4560} & \multicolumn{3}{|c|}{5321} \\
\hline Benefit/Cost \% & & \multicolumn{3}{|l|}{0.35} & \multicolumn{3}{|l|}{0.27} & \multicolumn{3}{|l|}{0.22} \\
\hline
\end{tabular}

Note:

$A=$ Value of specific property of conventional cementitious composites;

$\mathrm{B}=$ Improvement of value with respect to corresponding silica fume cementitious composites;

$\mathrm{C}=$ Benefit for specific property;

BSF0, BSF5, BSF10 means bacterial technology-enabled cementitious composites with $0 \%, 5 \%, 10 \%$ silica fume. 